\title{
Morphological and genetic description of two new species of philometrid nematodes (Philometridae) parasitic in needlefishes (Belonidae) from estuaries of Florida, USA
}

\author{
${\text { František } \text { Moravec }^{1} \mathbb{D} \text {, Micah D. Bakenhaster }}^{2}$, Seifu Seyoum $^{2}$ and Michael D. Tringali² \\ ${ }^{1}$ Institute of Parasitology, Biology Centre of the Czech Academy of Sciences, České Budějovice, Czech Republic; \\ ${ }^{2}$ Fish and Wildlife Research Institute, Florida Fish and Wildlife Conservation Commission, St. Petersburg, Florida, USA
}

\begin{abstract}
Two new species of philometrid nematodes (Philometridae) from needlefishes (Belonidae) in Florida are described based on morphological and genetic characteristics: Philometra aequispiculata sp. n. (males and females) collected from the ovary of Strongylura marina (Walbaum) (type host) and Strongylura notata (Poey), and Philometra notatae sp. n. (females) from the swimbladder of $S$. notata. Both species are described and illustrated based on light and scanning electron microscopical examinations. Morphologically, $P$. aequispiculata sp. n. differs from all congeners mainly in the unique structure of the distal tip of the gubernaculum, whereas $P$. notatae sp. n. is mainly characterised by the presence of eight markedly large cephalic papillae of the outer circle in gravid and subgravid females, the body length of the gravid female $(54 \mathrm{~mm})$ and by the absence of caudal projections. Molecular characterisation of the new species was assessed from phylogenetic analysis of mitochondrial cytochrome c oxidase I (COI) and SSU rRNA small-subunit ribosomal RNA (SSU) sequences among closely related philometrids by way of Bayesian inference. Phylogenetic reconstructions based on $\mathrm{COI}$ and SSU sequences show each of the new species comprise discrete ancestor-descendent lineages.
\end{abstract}

Keywords: Parasitic nematode, Philometra, Barracudia, marine fish, Strongylura, Atlantic Ocean, North America, Tampa Bay, Apalachicola Bay, integrated taxonomy

Philometrid nematodes (Philometridae) are widespread parasites of many freshwater, brackish-water and marine fishes, in which they usually exhibit a rather high degree of host specificity (Moravec et al. 2016). In addition to morphological features, each species is characterised by the infection site of its gravid females in the host's body, which is also important for the identification of philometrids (Moravec 1978, Moravec and Rohde 1992).

In hosts belonging to the beloniform family Belonidae (needlefishes), these parasites were first reported by Linton (1907) as Ichthyonema globiceps (Rudolphi, 1819) (=Philometra sp. - see Moravec 2008) from the musculature of Tylosurus acus (Lacépède) from Bermuda. Rasheed (1965) studied a broken female of Philometra sp. (misidentified as P. pellucida [Jägerskiöld, 1893] - see Moravec 2008), $55 \mathrm{~mm}$ long and with 'wide oesophageal lumen anteriorly', from 'Belone liura' (= apparently Strongylura leiura [Bleeker]) from Malabar, southern India, deposited in the British Museum (Nat. Hist.), London in 1935; unfortunately, the infection site in the host's body was not given. Nikolaeva and Parukhin (1968) found larvigerous females of Philometra sp., $75 \mathrm{~mm}$ long, in the swimbladder of Tylosurus crocodilus (Péron et Lesueur) (as Strongylura raphi- doma) in the Gulf of Mexico. Naidu and Thakare (1979) reported $P$. pellucida from the gonad of Xenentodon cancila (Hamilton) (a freshwater fish) in India, but this was an apparent misidentification (Moravec et al. 2018).

Hasegawa et al. (1991) recorded females of Philometra sp. from the subcutaneous tissue and anal fin of $T$. crocodilus from off Okinawa, Japan. Moravec and Rohde (1992) established two philometrid species, Philometra kohnae Moravec et Rohde, 1992 and Philometra lomi Moravec et Rohde, 1992, based on available subgravid and gravid females collected from the subcutaneous tissues of Tylosurus gavialoides (Castelnau) off Australia. Philometra sp. was reported by Petersen et al. (1993) from the musculature of the same host species (T. crocodilus) from off the Philippines and by Jacob and Palm (2006) off the southern coast of Java, Indonesia. It is highly probable that the nematodes reported by Petersen et al. (1993) and Jacob and Palm (2006) were conspecific with Philometroides indonesiensis Moravec, Walter et Yuniar, 2012, a species later described from T. crocodilus off Indonesia (Moravec et al. 2012).

From the Persian Gulf (off Iraq), Moravec and Ali (2005) described Philometra strongylurae Moravec et Ali, 2005 in Strongylura leiura and Strongylura strongylura 
(van Hasselt), and Philometra tylosuri Moravec et Ali, 2005 from T. crocodilus, both based on females collected from the hosts' subcutaneous tissues and musculature. The authors also mention finding the gravid female of Philometra sp. collected allegedly in the stomach of 'Belone sp.' from the Gulf of Beresin, Red Sea, in 1892. Subsequently, Moravec and Justine (2009) described Philometra dentigubernaculata Moravec et Justine, 2009 based on two males found in the oculo-orbit of T. crocodilus off New Caledonia. Philometra sp. was listed as a parasite of Strongylura notata (Poey) (see Moravec and Ali 2005, Moravec 2006) and Mohamed et al. (2010) reported Philometra sp. from $T$. crocodilus in the Arabian Gulf (off Saudi Arabia). Finally, Moravec and Bakenhaster (2012) described two subgravid females of Philometra sp. from the ovary of Strongylura marina (Walbaum) off Florida, USA.

Until now, no belonid-infecting philometrid has been molecularly characterised. However, numerous nematode-derived COI and SSU rRNA gene sequences have been made available in public databases (Floyd et al 2002, Holterman et al. 2006); these sequences have been used to validate (de Buron et al. 2011, Wang et al. 2015), identify (Palesse et al. 2011), and construct phylogenetic trees (Holterman et al. 2006, Černotíková et al. 2011) of nematode species.

During recent helminthological investigations of some estuarine fishes of Florida, philometrid specimens belonging to two undescribed species of Philometra Costa, 1845 were collected from sympatric, congeneric hosts, Atlantic needlefish (S. marina) and, the redfin needlefish (S. notata). One philometrid species infected gonads of both hosts while the other was found in the swimbladder of only S. notata. New important data on these nematodes are presented herein.

\section{MATERIALS AND METHODS}

Fish hosts of the new species were collected with haul seines from June 2017 through April 2019 during routine fisheries independent population monitoring conducted by the Fish and Wildlife Research Institute (FWRI) in Tampa and Apalachicola Bays. After capture, fish were immediately placed in plastic bags and packed in ice. Host specimens collected in Tampa Bay were returned within eight hours of capture to FWRI headquarters in St. Petersburg, Florida for laboratory evaluation, while those from Apalachicola Bay were shipped by commercial courier overnight on ice. In many cases, specimens of belonids were returned for routine pathological evaluation of grossly visible external abnormalities, most frequently jaw deformities characteristic of active or former infection by females of the copepod Colobomatus goodingi Cressey et Collette, 1970, and these fish were opportunely examined for helminths. To increase sample size and gather additional prevalence and intensity data, field crews also returned grossly normal specimens specifically for parasitological evaluation from September 2017 through April 2018.

Necropsies of fish included measurement of standard length (SL) and gross observations of external surfaces and visceral organs. Gonads were excised, placed in a petri dish, and cut open lengthwise (ovaries) or torn with forceps into pieces (testes), then rinsed with physiological saline. Grossly visible female nema- todes were isolated with fine paintbrushes. A dissecting microscope was used to check for male and small female nematodes in gonad rinsing and fine-tipped forceps were used to lift and isolate any recovered specimens. Only one fish specimen was observed during gross observation to host swimbladder-infecting worms and it was the only case when a swimbladder was also evaluated under magnification to check for male nematodes. The nematode specimens obtained for morphological study were fixed and preserved in 5\% formalin. For light microscopical examination, the nematodes were heat-killed with hot $\left(70-80{ }^{\circ} \mathrm{C}\right)$ tap water, then fixed and preserved in 5\% formalin, while those used for molecular evaluation were placed directly in $95 \%$ molecular grade ethanol.

For light microscopical examination, the nematodes were cleared in glycerine. Drawings were made with the aid of a Zeiss drawing attachment. Specimens used for scanning electron microscopy (SEM) were postfixed in $1 \%$ osmium tetroxide (in phosphate buffer), dehydrated through a graded acetone series, critical-point-dried and sputter-coated with gold; they were examined using a JEOL JSM-7401F scanning electron microscope at an accelerating voltage of $4 \mathrm{kV}$ (GB low mode). All measurements are in micrometres unless otherwise indicated. The fish nomenclature adopted follows FishBase (Froese and Pauly 2020).

\section{DNA extraction, PCR amplification and sequencing}

Tissue from ethanol-preserved specimens of two of each Philometra aequispiculata sp. n. from Strongylura marina and Philometra notatae sp. $\mathrm{n}$. from Strongylura notata was placed in a biomasher tube (RPI Research Products Mount Prospect, Chicago, Illinois). The ethanol was evaporated in an incubator at $37^{\circ} \mathrm{C}$ for one hour and a disposable homogeniser probe was employed to grind the tissue in $300 \mu \mathrm{l}$ of lysis buffer. Genomic DNA was extracted by using the PureGene DNA isolation kit (Gentra Systems Inc., Minneapolis, Minnesota) and the pellet was rehydrated in $100 \mu$ l of deionised water. The partial cytochrome oxidase subunit 1 (COI) was PCR amplified with the primers COIF, COIR (de Buron et al. 2011), and the SSU rDNA sequence with primers PhilonemaF, PhilPCRr, and ameb620f, ameb 620r as internal sequencing primers (Černotíková et al. 2011). PCR reactions had a final volume of $50 \mu \mathrm{l}$; each containg $150 \mathrm{ng}$ of the purified DNA, $50 \mu \mathrm{M}$ of dNTP mix, $0.25 \mu \mathrm{l}$ of $0.1-\mathrm{mg} / \mathrm{ml} \mathrm{BSA} ; 0.25 \mu 1$ of $100 \mu \mathrm{M}$ of each primer, $10 \mu \mathrm{l}$ of Taq polymerase buffer $(5 \times)$, $2.5 \mathrm{mM} \mathrm{MgCl}_{2}$ (Promega Corporation, Madison,Wisconsin; final concentration), and 1.25 units of Go Taq DNA polymerase (Promega Corporation). The reaction profile for COI was as follows: initial denaturation of $94{ }^{\circ} \mathrm{C}$ for $1.3 \mathrm{~min}, 35 \times\left(94{ }^{\circ} \mathrm{C}\right.$ for $40 \mathrm{~s}$, $47{ }^{\circ} \mathrm{C}$ for $40 \mathrm{~s}, 72{ }^{\circ} \mathrm{C}$ for $45 \mathrm{~s}$ ), and final extension at $72{ }^{\circ} \mathrm{C}$ for 5 min. For SSU rDNA the annealing temperature was, instead, $63{ }^{\circ} \mathrm{C}$. Amplified products were gel-purified (Agilent Technologies, Santa Clara, California) and sequenced from both directions by using Big Dye Terminator v 1.1 (Applied Biosystems, Inc., Waltham, Massachusetts). Cycle-sequenced products were precipitated and resuspended in Hi-Di Formamide and visualised on a 3130 Genetic Analyzer (Applied Biosystems, Inc.). Raw sequences were aligned and edited by using Sequencher (version 4.0; Gene Codes Corporation, Ann Arbor, Michigan) and sequence divergences were calculated by using MEGA (version 7.0, Tamura et al. 2013). 


\section{Phylogenetic analysis}

To evaluate the phylogenetic positions of the new nematode species, 50 sequences were initially extracted from GenBank, according to the BLAST homology score (Altschul et al. 1990). After initial alighment of the homologous SSU rDNA sequences available in GenBank, the longer sequences of the congeneric and other taxa were trimmed to that of the sequence range of the new species. Bayesian analysis (BA) (MrBayes, v3.0; Ronquist and Huelsenbeck 2003) was used to construct the phylogenetic trees. The nst 2 and GTR $+\mathrm{G}+1$ models were determined using the maximum-likelihood approach and Akaike information criterion (AIC) in the program MEGA, were implemented in MRBAYES for COI and SSU rDNA, respectively. Bayesian analysis was conducted for 10 metropolis-coupled Markov chain Monte Carlo generations, with posterior probabilities serched for $10^{6}$ generations (based on average standard deviation of split frequencies), of which the first $2.5 \times 10^{5}$ were considered the burn-in and excluded from the analysis. Trees were sampled every 1,000 generations during the run. The resulting tree file from MrBayes was used to construct the phylogenetic tree by using FigTree (http:// tree.bio.ed.ac.uk/software/figtree/). P-distance values between the putative new species and closely related sequences within the reconstructions were estimated by using MEGA.

New, supplemental COI sequences from a previously described species, Philometra diplectri Moravec et Bakenhaster, 2010, were also obtained by the above methods (GenBank Nos. MW326919, MW326920, MW326921) and included in the present phylogenetic analysis. The new specimens of $P$. diplectri were collected during June 2019 from the type host, Diplectrum formosum (Linnaeus), and type locality, northeastern Gulf of Mexico as part of an otherwise separate, ongoing study. Because our preliminary molecular evaluations revealed $P$. diplectri to be a near relative of one of the new species, these sequences were considered too important to reserve for a future more comprehensive manuscript and were therefore included in the current study.

\section{RESULTS}

\section{Philometridae Baylis et Daubney, 1926}

\section{Philometra aequispiculata sp. n.}

Figs. 1-5

ZooBank number for species:

urn:1sid:zoobank.org:act:BAAAA871-7DB1-41B1-B2CA-3B75DE667C81

Male (two specimens from Strongylura marina; holotype, measurements of paratype in parentheses. Measurements of 10 paratypes from Strongylura notata in brackets): Body filiform, whitish, 2.64 (2.48) [2.39-2.91] mm long, maximum width at middle of body 36 (42) [45-51]; anterior part of body tapering to anterior extremity, without usual constriction just posterior to cephalic end (Fig. 1H). Maximum width/body length ratio $1: 73$ (1: 59) [1:5363]. Cuticle smooth. Cephalic end rounded, 24 (30) [2430] wide. Oral aperture small, circular. Cephalic papillae 14 in number, arranged in 2 circles; outer circle formed by 4 submedian pairs, inner circle consists of 4 submedian and 2 lateral papillae (Figs. 1C, 2A,B). Pair of small, slit-like lateral amphids somewhat posterior to lateral cephalic pa- pillae (Figs. 1C, 2A,B). Oesophagus 294 (345) [390-516] long, comprising $11 \%(14 \%)$ [15-19\%] of body length, with slight inflation at anterior end measuring $27 \times 12(33$ $\times 18$ ) [24-30 × 12-18]; posterior part of muscular oesophagus overlapped by well-developed oesophageal gland with large cell nucleus; maximum width of gland 15 (21) [15-18]. Ventriculus small, 6 long, 9 wide. Nerve ring and oesophageal nucleus 123 (132) [123-162] and 237 (273) [207-396], respectively, from anterior extremity. Excretory pore 177 (192) [171-213] from anterior end.

Testis extending anteriorly approximately to level of posterior end of oesophagus (Fig. 1D). Posterior end of body blunt, 39 (36) [30-36] wide, with broad caudal mound formed by 2 lateral reniform portions well separated dorsally (Figs. 1L, 2C,D, 5C,D). Four pairs of small adanal papillae present in space between caudal mound and cloacal aperture: 2 pairs of small, markedly elevated papillae situated closely to cloacal aperture and 2 pairs of very flat, hardly visible papillae located externally to them; pair of small phasmids present dorsolaterally on caudal mound (Figs. 1L, 2D, 5D). Each portion of caudal mound with 1 subdorsal, minute circular depression (Figs. 1L, 2D, 5D). Spicules needle-like, equally long, with somewhat expanded proximal and sharply pointed distal tips (Figs. 1F,G,M, 4C,D, 5C,D); length of spicules 102 (102) [99$111]$, representing $3.9 \%$ (4.1\%) [3.6-4.2\%] of body length; maximum width of spicules 6 (6) [3-6]. Gubernaculum narrow, 69 (63) [60-69] long, with anterior portion somewhat dorsally bent; length of anterior bent part 33 (30) [2736], comprising 50\% (48\%) [39-55\%] of entire gubernaculum length (Figs. 1F,G,M, 4C,D). In lateral view, distal tip of gubernaculum with large dorsal triangular barb with smooth terminal part and 4 distinct transverse grooves on each side; proper extremity of gubernaculum posterior to barb rounded, with 2 deep lateral oblique grooves on each side, united to form 2 anteriorly oriented dorsal serrations; similar serrations also present in front of barb (Figs. 1J,K, 2E,F). Length ratio of gubernaculum and spicules $1: 1.55$ (1:1.62) [1:1.50-1.67]. Spicules and gubernaculum well sclerotised, yellowish, anterior part of gubernaculum and proximal ends of spicules colourless.

Gravid female (one incomplete specimen from $S$. marina, allotype): Body of fixed specimen brownish; anterior part of body tapered, with rounded end. Cuticle smooth. Body of specimen with missing posterior end $100 \mathrm{~mm}$ long, maximum width 1,115. Width of cephalic end 272. Cephalic papillae small, indistinct when laterally viewed (Fig. 1A). Oral aperture almost circular, surrounded by small cephalic papillae arranged in 2 circles and slightly outlined amphids; inner circle of papillae consists of 4 submedian and 2 lateral single papillae, outer circle formed by 4 submedian pairs of papillae. Oesophagus including well-developed anterior bulbous inflation $1.12 \mathrm{~mm}$ long; anterior inflation 612 long and 721 wide; maximum width of posterior part of oesophagus including gland 150. Oesophageal gland well-developed, opening into oesophagus just posterior to nerve ring, with large cell nucleus at middle (Fig. 1A). Nerve ring and oesophageal nucleus 367 and 666, respectively, from anterior extremity. Ventriculus 

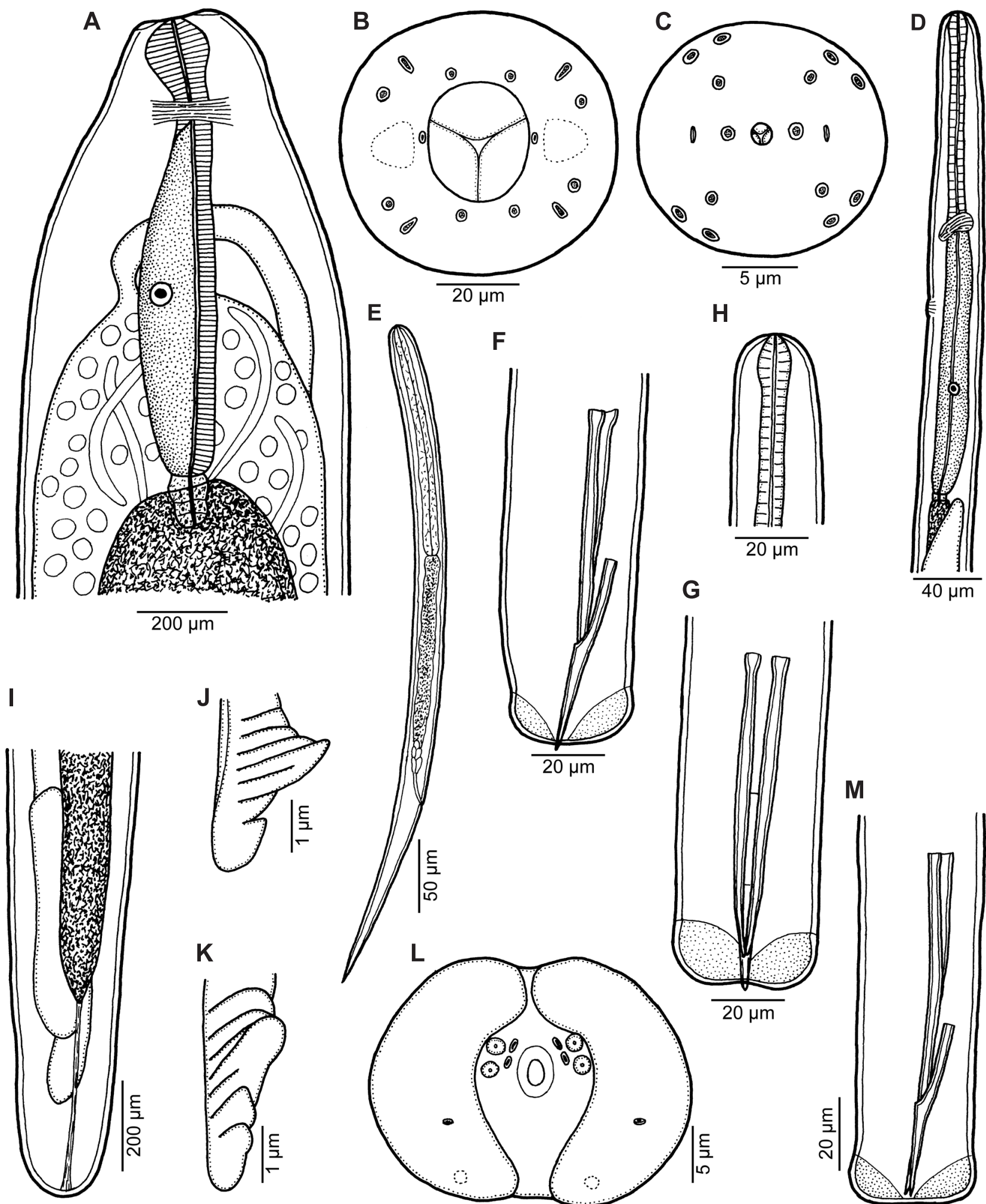

$\mathrm{H}$
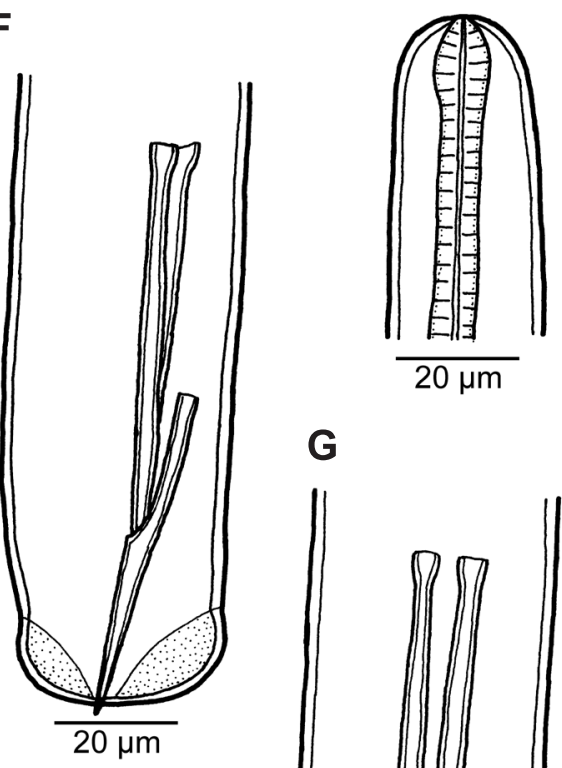

G

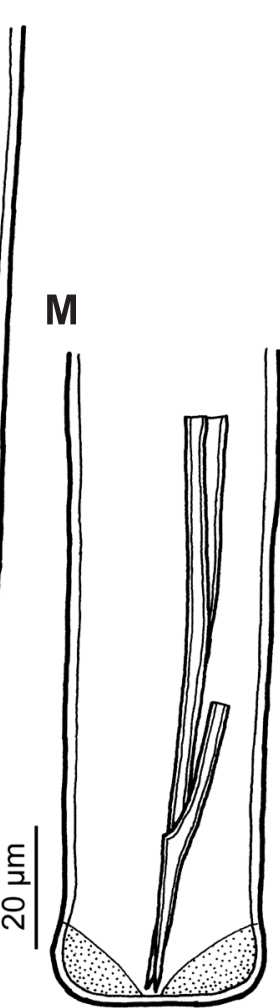

Fig. 1. Philometra aequispiculata sp. n. from Strongylura marina (Walbaum), Florida, USA. A - anterior end of gravid female, lateral view; $\mathbf{B}$ - cephalic end of subgravid female, apical view; $\mathbf{C}$ - cephalic end of male, apical view; $\mathbf{D}$ - anterior end of male, lateral view; $\mathbf{E}$ - larva; F, G - posterior end of male, lateral and ventral views, respectively; $\mathbf{H}$ - cephalic end of male, lateral view; $\mathbf{I}$ - posterior end of nongravid female, lateral view; $\mathbf{J}, \mathbf{K}$ - distal tip of gubernaculum, lateral and subdorsal views, respectively; $\mathbf{L}$ - caudal end of male, apical view; $\mathbf{M}$ - posterior end of male (another specimen), lateral view. 


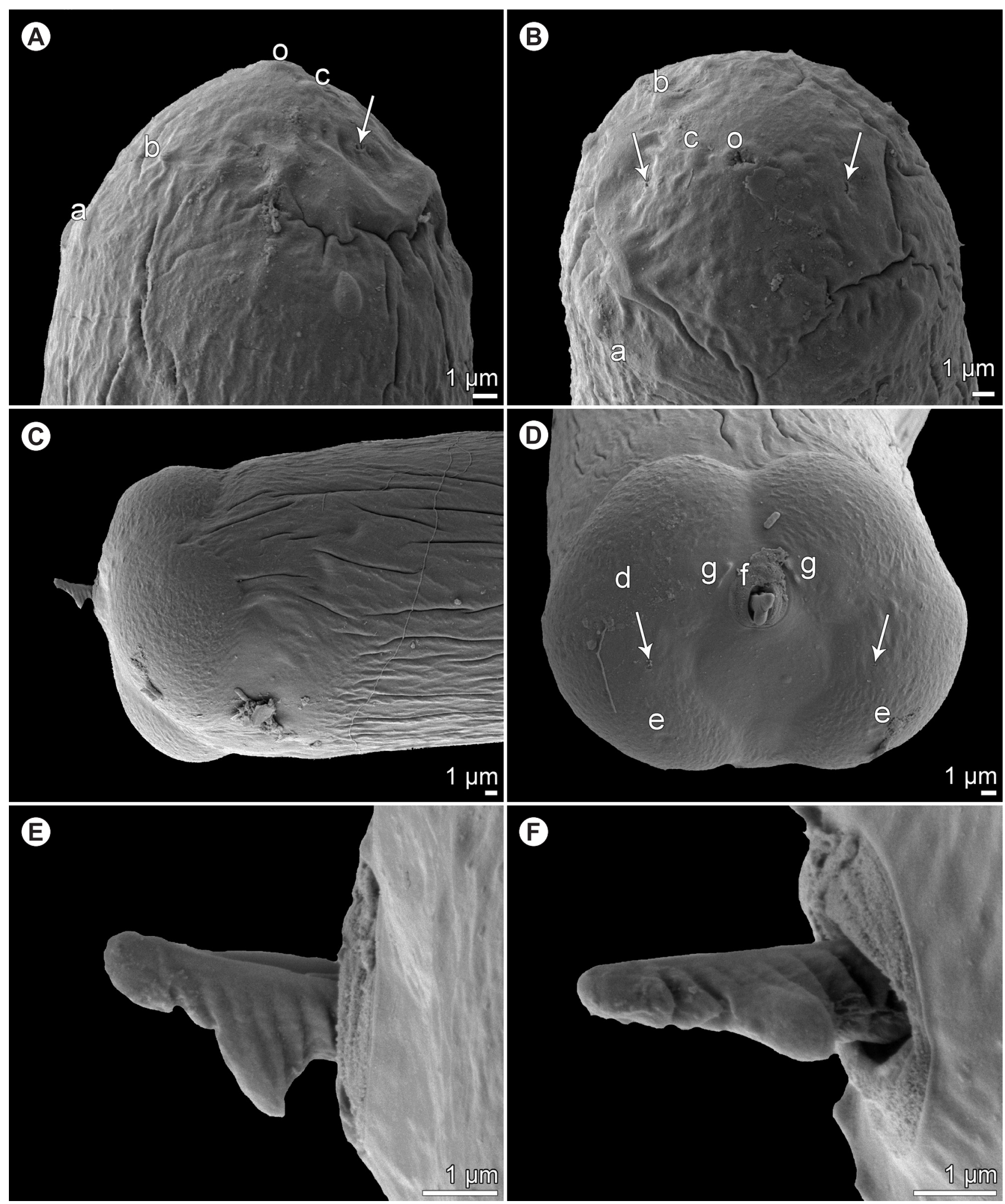

Fig. 2. Philometra aequispiculata sp. n. from Strongylura marina (Walbaum), Florida, USA; scanning electron micrographs of male. A, B - cephalic end, sublateral and apical views, respectively (arrows indicate amphids); C, D - caudal end, lateral and apical views, respectively (arrows indicate phasmids); E, F - distal end of gubernaculum, lateral and subdorsal views, respectively. Abbreviations: $\mathrm{a}$ - pair of cephalic papillae of outer circle; $\mathrm{b}$ - submedian cephalic papilla of inner circle; $\mathrm{c}$ - lateral cephalic papilla of inner circle; $\mathrm{d}$ - caudal mould; e - cuticular depression; $\mathrm{f}$ - cloaca; $\mathrm{g}$ - two elevated adanal papillae; $\mathrm{o}$ - oral aperture. 

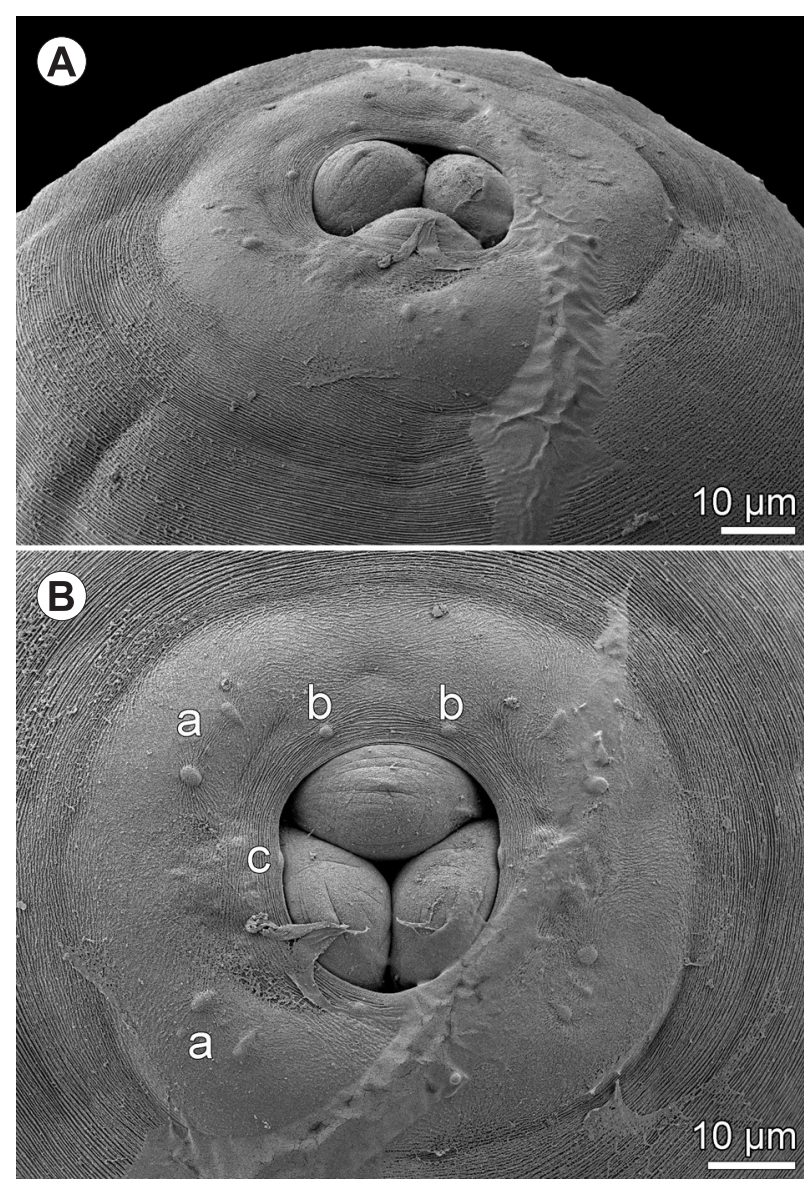

Fig. 3. Philometra aequispiculata sp. n. from Strongylura marina (Walbaum), Florida, USA; scanning electron micrographs of subgravid female. A - anterior end of body, subapical view; B - cephalic end, apical view. Abbreviations: a - pair of cephalic papillae of outer circle; $b$ - submedian cephalic papilla of inner circle; $\mathrm{c}$ - lateral cephalic papilla of inner circle.

small, 30 long, 99 wide. Intestine brown. Vulva absent. Anterior ovary reflexed near anterior body end (Fig. 1A). Uterus occupying most space of body, filled with numerous eggs and larvae (Fig. 1A,E). Larvae $(n=5)$ 489-495 long, maximum width 18; length of oesophagus 156-186 (32-38\% of body length), of sharply pointed tail 138-159 (28-32\% of body length). Posterior end of female specimen absent.

Subgravid female (one specimen from $S$. marina): Body of fixed specimen brownish, $74 \mathrm{~mm}$ long, maximum width 680; maximum width/body length ratio $1: 109$. Width of cephalic end 177. Cephalic structures (Figs. 1B, $3 \mathrm{~A}, \mathrm{~B})$ essentially identical with those in gravid female. Oesophagus including anterior bulbous inflation $1.05 \mathrm{~mm}$ long, comprising $1.4 \%$ of body length; anterior inflation 612 long and 680 wide; maximum width of posterior part of oesophagus including gland 136 . Nerve ring and oesophageal nucleus 163 and 653, respectively, from anterior extremity. Intestine brown, straight, ending blindly; posterior end of intestine atrophied, forming ligament 721 long attached ventrally to body wall close to posterior extremity. Vulva and anus absent. Ovaries reflexed near body ends.
Uterus filled with numerous eggs. Posterior end rounded, 299 wide, without caudal projections.

Nongravid female (one complete and one incomplete mature specimens without eggs from $S$. marina; measurements of additional three specimens from $S$. notata in parentheses): Body whitish, that of complete specimen 35.0 $\mathrm{mm}$, of incomplete specimen 15.1 (2.34-2.49) $\mathrm{mm}$ long, maximum width 286-503 (48-60); maximum width/body length ratio $1: 114(1: 141-152)$. Width of cephalic end 109-163 (30). Oesophagus including anterior bulbous inflation 925-1,020 (411-480) long, comprising 3\% (17$21 \%$ ) of body length; its anterior inflation 90-114 (30-36) long and 87-111 (18-21) wide (Fig. 4A). Nerve ring and oesophageal nucleus 216-286 (165-189) and 135-598 (267-315), respectively, from anterior extremity. Ventriculus 15 (9-12) long, 33-81 (24) wide. Intestinal ligament 503 (60-75) long (Figs. 1I, 4E). Vulva absent (rudimentary vulva at $1.63-1.73 \mathrm{~mm}$ from anterior extremity, i.e. at $69-$ $70 \%$ of entire body end; Fig. 4F). Uterus empty. Posterior end rounded, 163 (36-42) wide, without caudal projections (Figs. 1I, 4E).

Type host: Atlantic needlefish Strongylura marina (Walbaum) (Belonidae, Beloniformes); 389-508 mm standard length (SL).

Other host: Redfin needlefish Strongylura notata (Poey) (Belonidae, Beloniformes); 148-379 mm SL.

Site of infection: Gonad (ovary and testis).

Type locality: Gulf of Mexico, specifically Tampa Bay $(27.5474,-82.6333 ; 27.8287,-82.4420)$ and Apalachicola Bay (29.6997, -84.7782), Florida, USA (collected 7 November 2017, and 15 March and 13 June 2018).

Prevalence and intensity: Strongylura marina: $26 \%$ (5 fish infected/19 fish examined); 1-3 (mean 1.4) nematode specimens per fish. Strongylura notata: 19\% (20/105); 1-4 (mean 1.4).

Deposition of type specimens: Male holotype and female allotype (both mounted on SEM stubs) and 4 paratypes in the Helminthological Collection of the Institute of Parasitology, BC CAS, České Budějovice, Czech Republic (Cat. No. $\mathrm{N}-1223) ; 14$ paratypes in the Smithsonian National Museum of Natural History, Washington, USA (Cat. Nos. USNM 1640964 and USNM 1640965, respectively).

Additional material: Two female specimens taken from gonads of the type host were used for gene sequencing (GenBank Nos. MW328558, MW328559) and are no longer available for examination.

Etymology: The specific name aequispiculata relates to the fact that spicules of this nematode species are equally long.

Remarks. The present data show that nematodes collected from $S$. marina and $S$. notata are morphologically and biometrically practically identical, they have the same site of infection in the host and localities, their hosts are congeneric, so that we consider them to be representatives of the same species.

To date, the following six nominal species of philometrid nematodes are known to parasitise belonid fishes: Philometra dentigubernaculata, P. kohnae, P. lomi, P. strongylurae, P. tylosuri and Philometroides indonesiensis, whereas the previous records of Philometra globiceps 
A

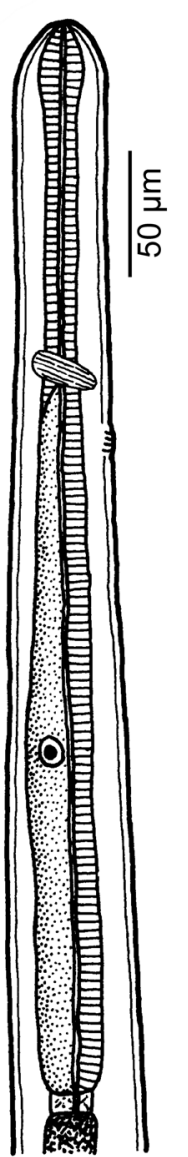

B

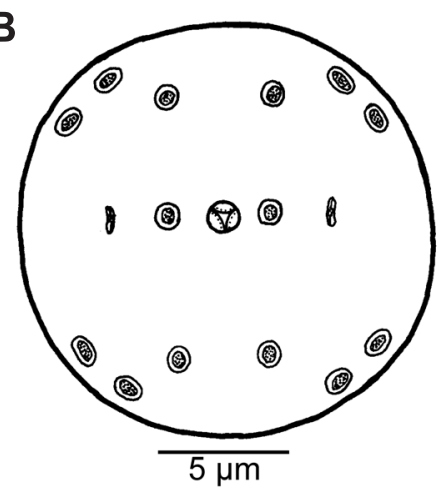

E

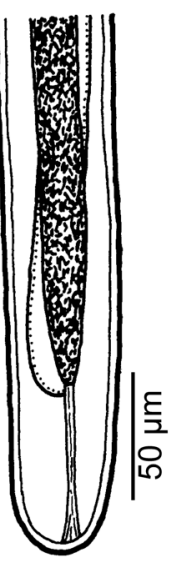

C

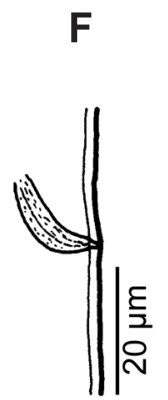

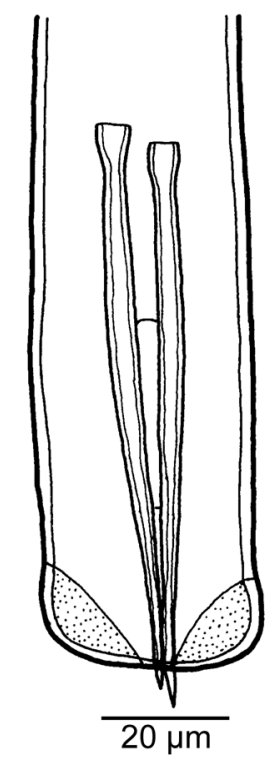

D

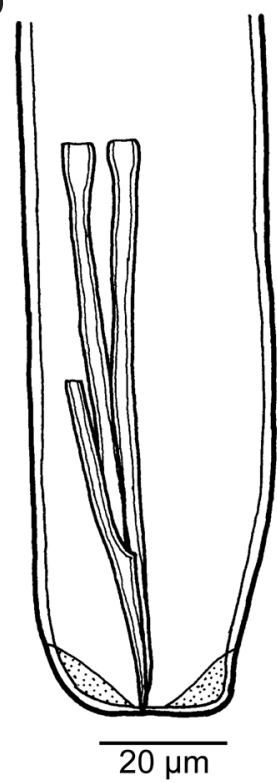

Fig. 4. Philometra aequispiculata sp. n. from Strongylura notata (Poey), Florida, USA. A - anterior end of nongravid female, lateral view; B - cephalic end of male, apical view; C, D - caudal end of male, ventral and lateral views, respectively; $\mathbf{E}$ - posterior end of nongravid female, lateral view; $\mathbf{F}$ - vulva of nongravid female, lateral view.

and $P$. pellucida from these hosts were evidently misidentifications (see above). However, in contrast to P. aequispiculata sp. n., all these species infect different sites in the host (subcutaneous tissues, musculature or oculo-orbits), being mostly described solely from available gravid and subgravid females (the male is known only for $P$. dentigubernaculata). Generally, in addition to morphological features, philometrid species are characterised by the site of infection in the host, particularly that of their gravid females (Moravec and Rohde 1992).

The new species differs from $P$. dentigubernaculata in a distinctly shorter body of the male $(2.39-2.91 \mathrm{~mm}$ vs 4.65-4.99 mm), in the spicule length/body length ratio (3.6-4.2\% vs 2.3\%), a shorter gubernaculum (60-69 $\mu \mathrm{m} v s$ $84-90 \mu \mathrm{m})$ and mainly in a different structure of the gubernaculum distal tip (with transverse grooves $v s$ without transverse grooves). Moreover, both species have a different site of infection in the host (gonad vs oculo-orbits) and they occur in very distant localities (Gulf of Mexico vs South Pacific Ocean).

In contrast to $P$. aequispiculata sp. n., $P$. kohnae and $P$. strongylurae possess markedly large, dome-shaped cephalic papillae (vs cephalic papillae very small, hardly visible) and their anterior oesophageal bulb is conspicuously large, strongly muscular, distinctly separated from the remaining portion of the oesophagus (vs bulb much less developed, not separated); they also differ in the site of infection (subcutaneous tissues $v s$ gonad) and their respective hosts have strongly allopatric ranges (Western Atlantic Ocean vs Indo-West Pacific region).

The gravid female of $P$. lomi has a much longer oesophagus $(3.3 \mathrm{~mm} v s 1.12 \mathrm{~mm})$ provided with a distinct extention of the oesophagus between its anterior bulb and the nerve ring ( $v s$ without such an extention), whereas the oesophagus of nongravid females of $P$. tylosuri is distincty longer than that of subgravid and gravid females of the new species $(1.63-1.65 \mathrm{~mm}$ vs $1.02-1.12 \mathrm{~mm})$, representing $2.3-3.5 \%$ ( $v s 1.4 \%$ in a subgravid female) of the body length, and their caudal end bears a pair of minute caudal projections ( $v s$ caudal projections absent). Philometra lomi and P. tylosuri are parasites of the host's subcutaneous tissues (latter species also in musculature) ( $v s$ in gonad) and they occur in the Indo-Pacific region ( $v s$ in North Atlantic Ocean).

Philometroides indonesiensis mainly differs from Philometra aequispiculata sp. $\mathrm{n}$. in that the body surface of its gravid female bears sparsely distributed small cuticular bosses ( $v s$ cuticular bosses absent). In addition, these species utilise hosts belonging to different fish genera (Tylosurus Cocco vs Strongylura van Hasselt), they differ in the 

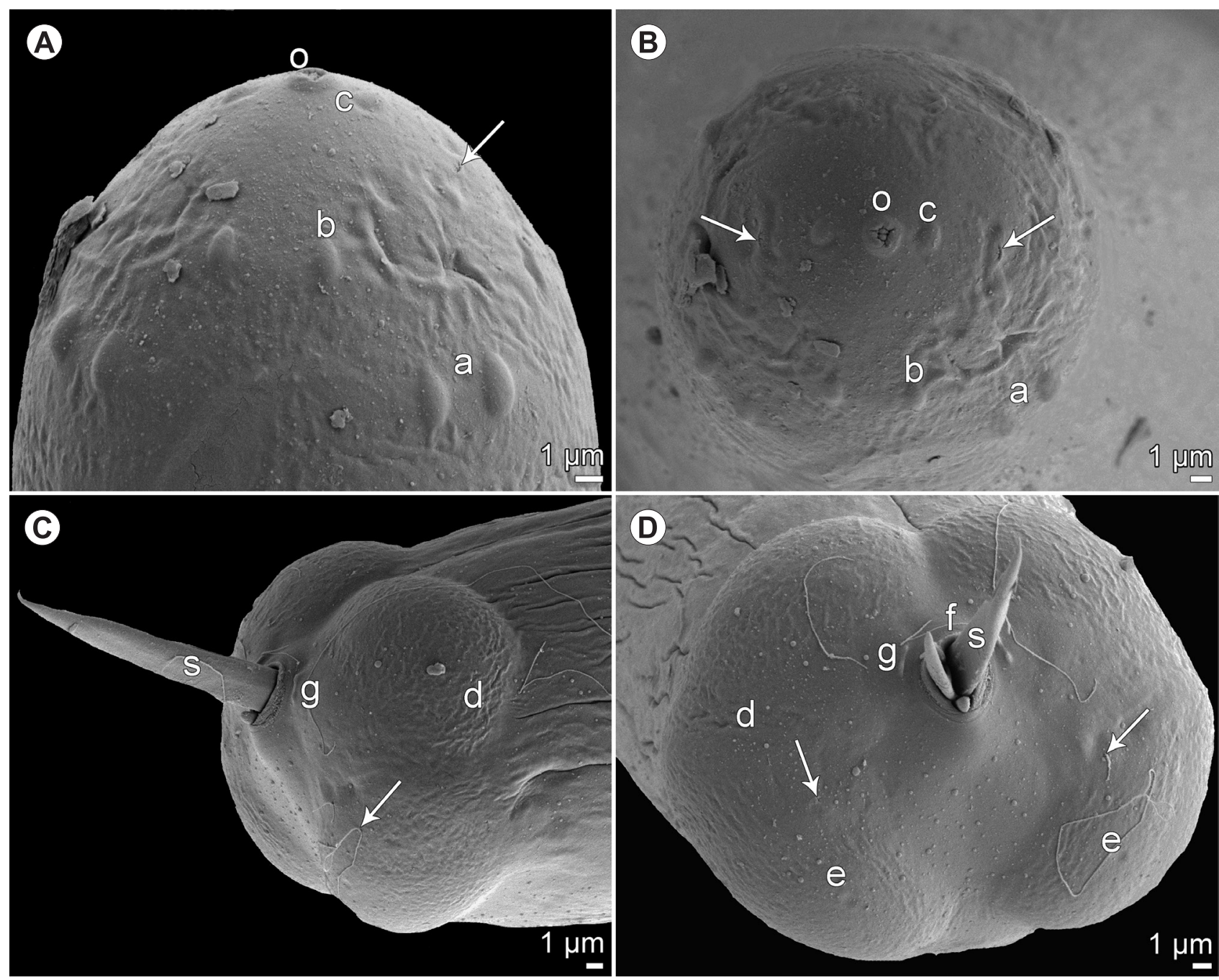

Fig. 5. Philometra aequispiculata sp. n. from Strongylura notata (Poey), Florida, USA; scanning electron micrographs of male. A, B - cephalic end, dorsoventral and apical views, respectively (arrows indicate amphids); C, D - caudal end, sublateral and apical views, respectively (arrows indicate phasmids). Abbreviations: a - pair of cephalic papillae of outer circle; $\mathrm{b}$ - submedian cephalic papilla of inner circle; $\mathrm{c}$ - lateral cephalic papilla of inner circle; $\mathrm{d}$ - caudal mound; $\mathrm{e}$ - cuticular depression; $\mathrm{f}$ - cloaca; $\mathrm{g}$ - two elevated adanal papillae; $\mathrm{o}-$ oral aperture; $\mathrm{s}-$ spicule.

site of infection (musculature $v s$ gonad) and occur in very distant localities (Indian Ocean vs North Atlantic Ocean). Therefore, the present nematodes from the gonads of $S$. marina and $S$. notata are considered to be a new species. Its characteristic feature is the structure of the distal gubernaculum tip, by which it can be distinguished from all other Philometra spp. with known males. Philometra aequispiculata $\mathrm{sp} . \mathrm{n}$. is the sixth nominal species of this genus described from the Belonidae and the first gonad-infecting species of Philometra from these hosts (needlefishes).

\section{Philometra notatae sp. n.}

Figs. 6-8

ZooBank number for species:

urn:Isid:zoobank.org:act:CCDC5D2D-89EE-4FD4-83F7-1CD078BF162A

Gravid female (one larvigerous specimen, holotype): Body of fixed specimen yellowish; anterior half of body broader than posterior one. Anterior part of body tapered, truncated (Fig. 6A). Cuticle smooth. Length of body 54.1 mm, maximum width $1.80 \mathrm{~mm}$; width of cephalic end 394. Maximum width/body length ratio $1: 30$. Oral aperture circular, surrounded by cephalic papillae arranged in 2 circles; inner circle of papillae consists of 4 submedian and 2 lateral small single papillae, outer circle formed by 4 submedian pairs of large papillae; amphids indistinct (Figs. 6C, 7A,C). Oesophagus including well-developed anterior bulbous inflation $2.58 \mathrm{~mm}$ long, representing $4.8 \%$ of body length; anterior bulbous inflation 245 long and 299 wide; maximum width of posterior part of oesophagus including gland 272. Oesophageal gland well developed, opening into oesophagus just posterior to nerve ring, provided with large cell nucleus situated $1.80 \mathrm{~mm}$ from anterior end of body (Fig. 6A). Nerve ring 394 from anterior extremity. Ventriculus small, 54 long, 109 wide. Intestine brownish, very broad, ending blindly; posterior end of intestine atrophied, forming ligament 748 long attached ventrally to body wall close to posterior extremity (Fig. 6B). Vulva and anus absent. Ovaries narrow, making coils near body ends (Fig. 6A,B). Uterus occupying most space of body, filled 


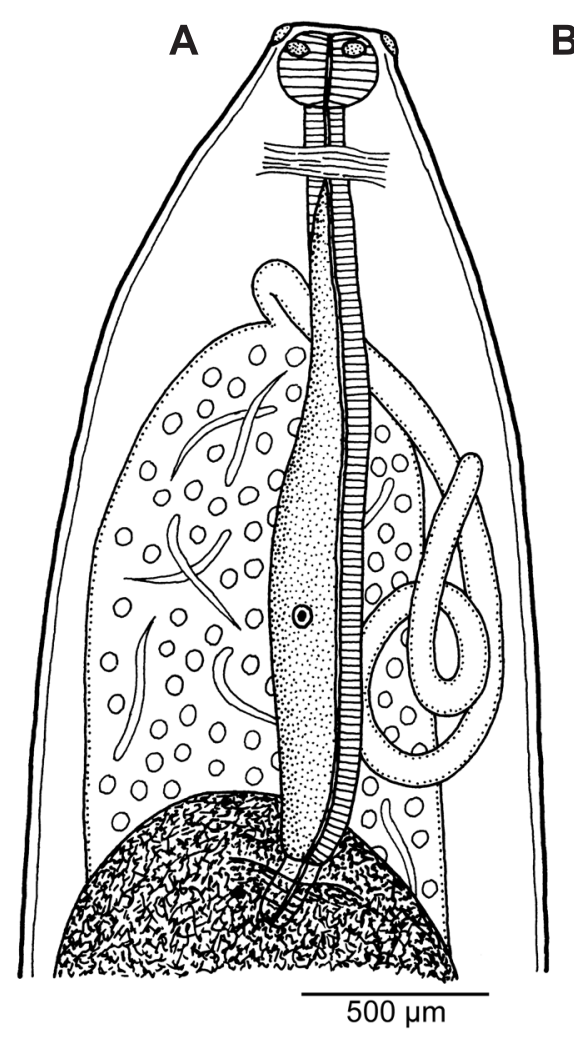

B

C

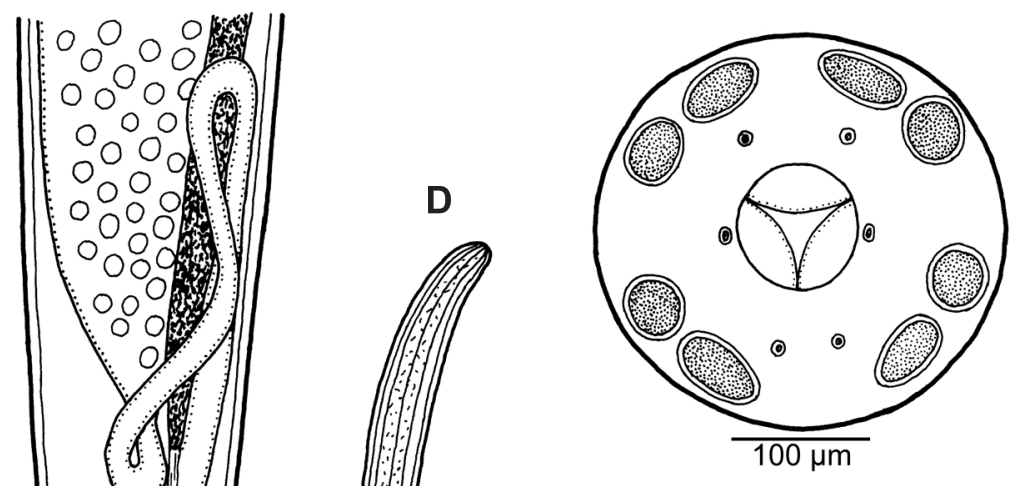

E
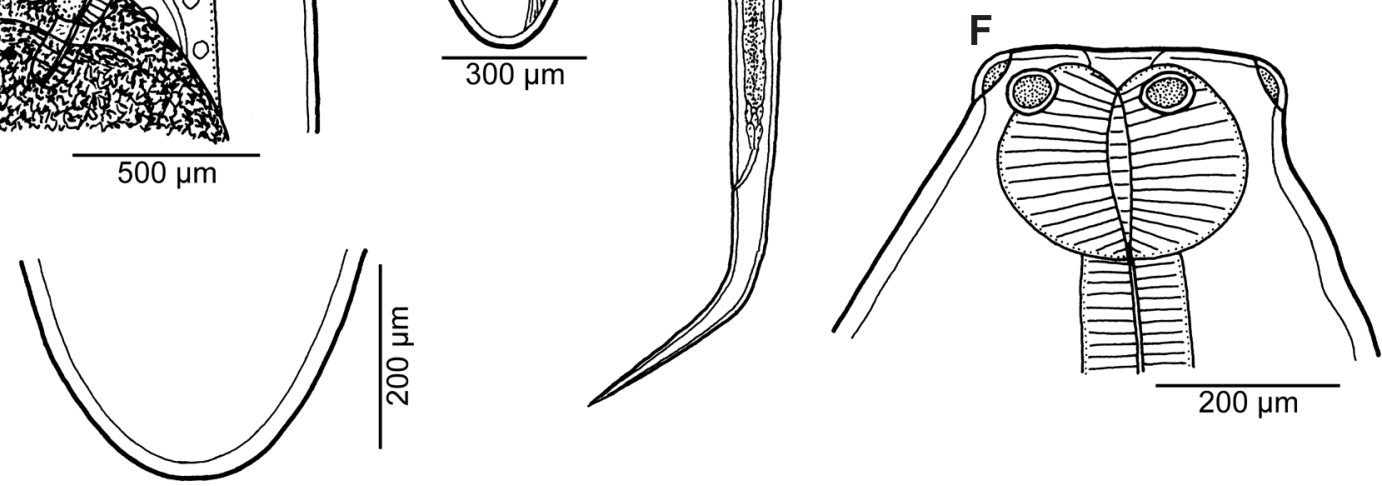

Fig. 6. Philometra notatae sp. n. from Strongylura notata (Poey), Florida, USA, gravid female. A - anterior end of body, lateral view; B - posterior end of body, lateral view; C - cephalic end, apical view; D - larva from uterus, lateral view; $\mathbf{E}$ - shape of caudal end, lateral view; $\mathbf{F}$ - cephalic end, lateral view.

with numerous eggs and larvae (Fig. 6A). Larvae $(n=5)$ 390-420 long, maximum width 15-18; length of oesophagus $120-129$ (31\% of body length), of sharply pointed tail 96-105 (25\% of body length) (Fig. 6D). Posterior end of female rounded, 272 wide, without caudal projections Fig. $6 \mathrm{~B}, \mathrm{E})$.

Subgravid female (two complete and one incomplete ovigerous specimens, paratypes): Body of fixed specimens whitish to yellowish, 46.6-55.8 mm long, maximum width 884-1,564; maximum width/body length ratio 1 : 33-36. Width of cephalic end 381 . Oral aperture circular. Number, size and arrangement of cephalic papillae as in gravid female (Fig. 7B,D). Oesophagus including anterior bulbous inflation 2.15-2.18 mm long, comprising 3.9-4.6\% of body length; anterior bulb 177-218 long and 286-299 wide; maximum width of posterior part of oesophagus including gland 163-258. Nerve ring and oesophageal nucleus 381408 and $1.43 \mathrm{~mm}$, respectively, from anterior extremity. Intestine brownish, straight, ending blindly; posterior end of intestine atrophied, forming ligament 394-870 long attached ventrally to body wall close to posterior extremity. Vulva and anus absent. Uterus filled with numerous eggs.
Posterior end rounded, 245-299 wide, without caudal projections.

Male: Not known.

Type host: Redfin needlefish Strongylura notata (Poey) (Belonidae, Beloniformes); $381 \mathrm{~mm}$ standard length (SL).

Site of infection: Swimbladder.

Type locality: Gulf of Mexico, specifically Tampa Bay (27.8137, -82.4026), USA (collected 18 April 2019).

Prevalence and intensity: $0.9 \%$ (1 fish infected/105 fish examined); 6 nematode specimens.

Deposition of type specimens: Holotype and paratype (mounted on SEM stubs) in the Helminthological Collection of the Institute of Parasitology, BC CAS, České Budějovice, Czech Republic (Cat. No. N-1224); 3 paratypes in the Smithsonian National Museum of Natural History, Washington, USA (Cat. No. USNM 1640966).

Etymology: The specific name notatae is the genitive form of the host's species name.

Remarks. The new species $P$. notatae sp. n. is noted for the presence of eight conspicuously large cephalic papillae of the external circle in gravid and subgravid females, a 

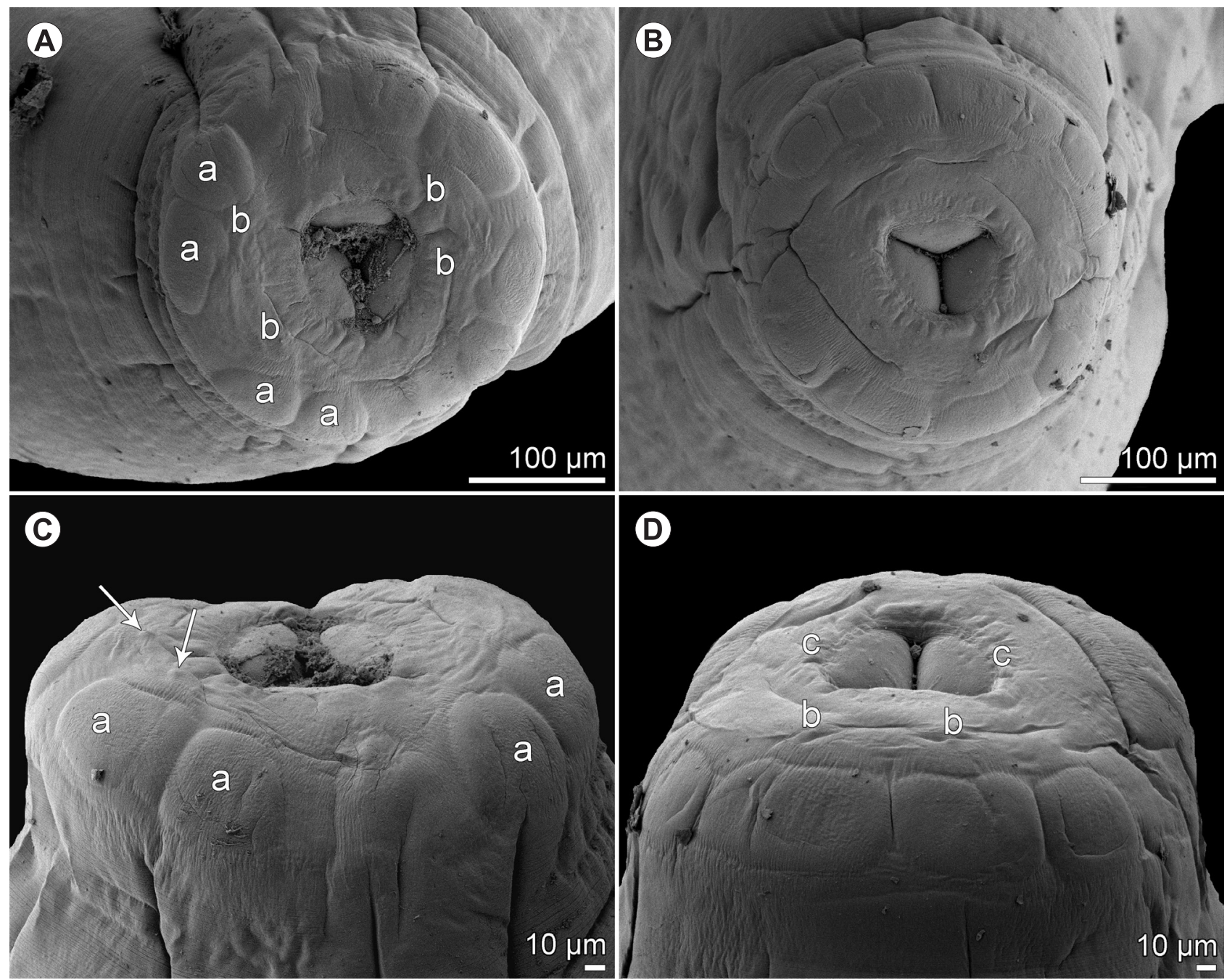

Fig. 7. Philometra notatae sp. n. from Strongylura notata (Poey), Florida, USA; scanning electron micrographs of females. A, B cephalic end of gravid and subgravid female, respectively, apical views; $\mathbf{C}$ - cephalic end of gravid female, sublateral view (arrows indicate inner submedian papillae); D - cephalic end of subgravid female, dorsal view. Abbreviations: a - submedian cephalic papilla of outer circle; b - submedian cephalic papilla of inner circle; $c$ - lateral cephalic papilla of inner circle.

feature by which it resembles only seven other congeneric species parasitising marine or brackish-water fishes: Philometra beninensis Obiekezie, 1986 from the subcutaneous tissue of Polydactylus quadrifilis (Cuvier) (Polydactylidae) in the eastern Central Atlantic (off Nigeria); Philometra cynoscionis Moravec, de Buron et Roumillat, 2006 from the subcutaneous tissue of Cynoscion nebulosus (Cuvier) (Sciaenidae) in the West Atlantic Ocean (off the USA); $P$. kohnae from the subcutaneous tissue of Tylosurus gavialoides (Castelnau) (Belonidae) in the Pacific Ocean off Australia; Philometra overstreeti Moravec et de Buron, 2006 from the tissue among teeth of Paralichthys lethostigma Jordan et Gilbert (Paralichthyidae) in the West Atlantic Ocean (off the USA); Philometra salgadoi Vidal-Martínez, Aguirre-Macedo et Moravec, 1995 from the occular cavity of Epinephelus morio (Valenciennes) (Serranidae) in the Gulf of Mexico; P. strongylurae from the subcutaneous tissue, musculature and gills of Strongylura leiura and Strongylura strongylura (Belonidae) in the Persian Gulf (off Iraq); and P. diplectri from the head tissues and the operculum of Diplectrum formosum in the Gulf of Mexi- co (Obiekezie 1986, Obiekezie and Anders 1991, Moravec and Rohde 1992, Vidal-Martínez et al. 1995, Moravec et al. 2001, 2006, Moravec and de Buron 2006, Moravec and Bakenhaster 2010).

However, in contrast to the new species, the gravid female of $P$. salgadoi is much longer (92-111 mm vs 54 $\mathrm{mm}$ ) and possesses a pair of caudal projections ( $v s$ caudal projections absent). The body of gravid females of all other above-mentioned species, except for $P$. kohnae, is distinctly shorter than that of $P$. notatae sp. n., not exceeding $35 \mathrm{~mm}$, and these also differ in some other features: P. beninensis has a shorter oesophagus (1.04 $\mathrm{mm}$ vs 2.58 $\mathrm{mm})$ and its oesophageal bulb is narrower $(110 \mu \mathrm{m}$ vs 299 $\mu \mathrm{m}) ;$ P. cynoscionis has a shorter oesophagus (1.22-1.78 $\mathrm{mm}$ vs $2.58 \mathrm{~mm}$ ) and a smaller oesophageal bulb (90-135 $\times 114-165 \mu \mathrm{m}$ vs $245 \times 299 \mu \mathrm{m}) ;$ P. overstreeti has a shorter oesophagus (1.02-1.33 $\mathrm{mm}$ vs $2.58 \mathrm{~mm})$ and a smaller oesophageal bulb $(51-68 \times 63-87 \mu \mathrm{m} v s 245 \times 299 \mu \mathrm{m})$; $P$. strongylurae differs in the maximum width/body length ratio $(1: 17-24$ vs $1: 30)$ and the relative length of the oesophagus to the body length (9-11\% vs 5\%); and $P$. 


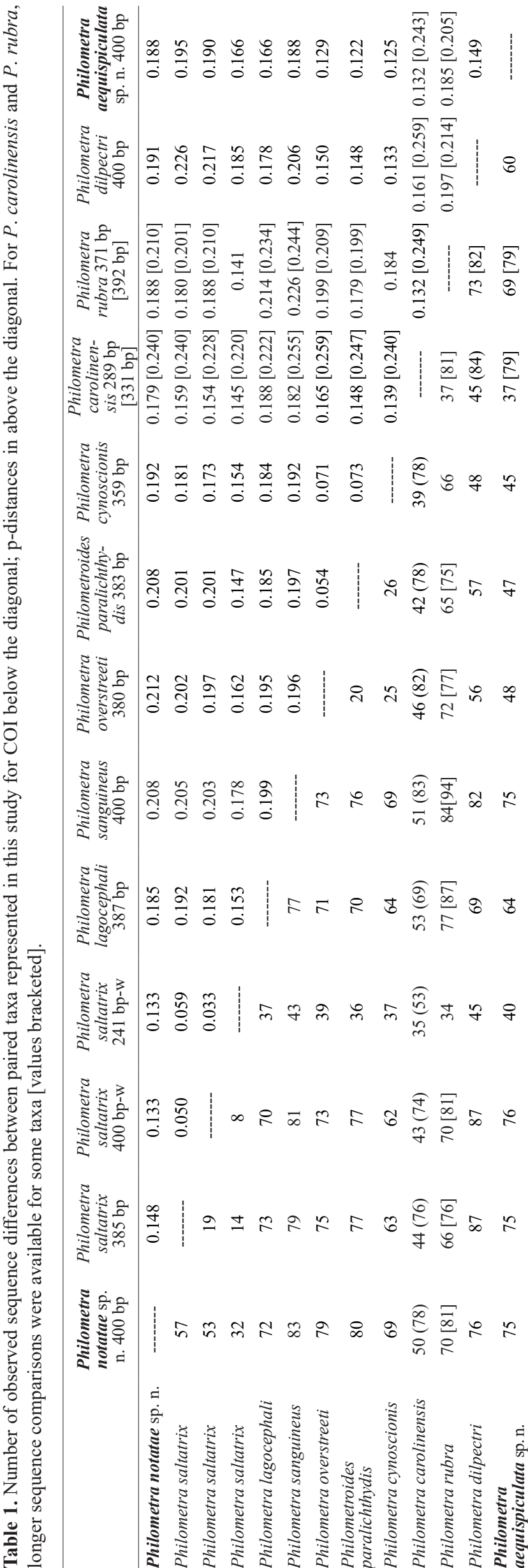

diplectri in a shorter oesophagus $(1.07-1.33 \mathrm{~mm}$ vs 2.58 $\mathrm{mm})$ and a smaller oesophageal bulb (48-57 × 111-132 $\mu \mathrm{m} v s 245 \times 299 \mu \mathrm{m})$. The female of $P$. kohnae is reported to be $34-76 \mathrm{~mm}$ long, but the length of its oesophagus represents only $3-4 \%$ ( vs approximately $5 \%$ ) of the body length, the infection site in the host is different (encapsulated in subcutaneous pouches $v s$ in swimbladder), the host belongs to a different genus (Tylosurus vs Strongylura) and their respective host species have strongly allopatric ranges (South Pacific Ocean endemic to Australia vs western North Atlantic Ocean estuaries of the Americas and West Indies).

To date, $P$. notatae sp. $\mathrm{n}$. is the only nominal species of Philometra with gravid females located in the swimbladder of a belonid host. The gravid female of Philometra sp. reported by Nikolaeva and Parukhin (1968) from the swimbladder of Tylosurus crocodilus in the Gulf of Mexico (see above) might belong to a different, so far undescribed species (considering a different genus of the host), although conspecificity of both these forms cannot be excluded.

While no relevance to infection by $P$. notatae sp. n. is suggested, the type host specimen exhibited several abnormalities that should nevertheless be mentioned. Its jaw had a lesion grossly consistent with putative histiocytic sarcoma previously reported for this species in Florida (Kiryu et al. 2018) and a tumor-like mass (approximately $40 \mathrm{~mm}$ diameter) of undetermited nature that caused marked distension of the fish's abdomen near the anal fin. Various other internal abnormalities were noted including a deformed ovary and an intense infection of the liver and gall-bladder by larval cestodes. Full pathological evaluation of these lesions remains incomplete.

\section{Sequence data}

For both $P$. notatae sp. n. and $P$. aequispiculata sp. n., we obtained COI sequences of 400 base pairs (bp) in length (GenBank accession numbers MW326917, MW326918 and MW326915, MW326916, respectively); for the SSU rDNA, we obtained sequences of 1,671 bp and 1,487 bp long, respectively (GenBank accession numbers MW328560, MW328561 and MW328558, MW328559). As expected, there were no stop codons or indels in the COI sequences. A total of 28 homologous matches of related taxa were retained in BLAST searches involving COI haplotypes for the new species. P-distance values between $P$. notatae sp. n. and the two most closely related species, Philometra saltatrix Ramachandran, 1973 and Philometra lagocephali Moravec et Justine, 2008, were 0.133 and 0.185 ; between $P$. aequispiculata sp. n. and its three most closely related species, $P$. diplectri, $P$. overstreeti, and Philometroides paralichthydis Moravec et Justine, 2006, p-distance values ranged from 0.122 to 0.149 . These distances were higher on average than those between pairs of recognised taxa. Table 1 provides the number of base-pair differences and $\mathrm{p}$-distance values amongst representative taxa based on available COI sequences.

For SSU rDNA, the number of homologous sequences retained was 38 in BLAST searches; after trimming, the alignment length was 1846 bp, indicating a substantial in- 

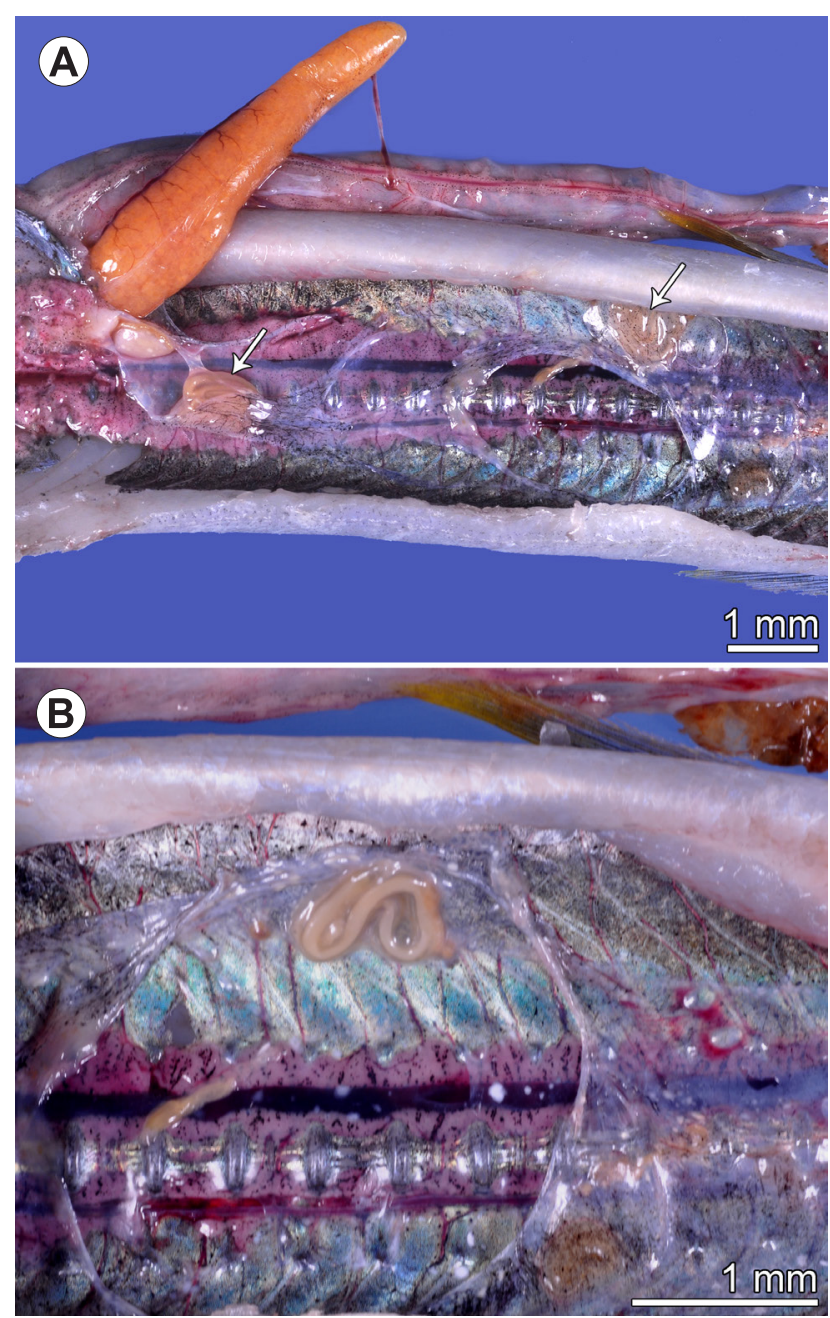

Fig. 8. Females of Philometra notatae sp. $\mathrm{n}$. in the swimbladder of Strongylura notata (Poey), Florida, USA. A - two specimens (indicated by arrows); $\mathbf{B}$ - one specimen (higher magnification).

clusion of indels. The $\mathrm{p}$-distance values between $P$. notatae sp. n. and its six most closely related species ranged from 0.007 to 0.015 ; whilst in comparisons among these six taxa, values ranged from 0.002 to 0.019 . Similarly, between $P$. aequispiculata $\mathrm{sp}$. $\mathrm{n}$. and its four most closely related species, p-distance values ranged from 0.011 to 0.021 ; whilst in comparisons among these four taxa, values ranged from 0.008 to 0.018 . Tables 2 and 3 provide the number of basepair differences and p-distance values amongst representative taxa based on available SSU rDNA sequences.

\section{Phylogenetic reconstructions}

Bayesian inference yielded a single topology for COI wherein both putative new species were clustered uniquely in fully supported clades (Fig 9). Haplotypes of $P$. notatae sp. n. clustered with $99 \%$ Bayesian support and were reciprocally monophyletic to a clade containing haplotypes of $P$. saltatrix. However, Bayesian support for the distinguishing node was only 68\%. Philometra rubra (Leidy, 1856) resolved as the most recent common (maternal) ancestor to these two taxa. The clade containing observed haplotypes of $P$. aequispiculata sp. n. was also monophyletic, having
$100 \%$ support. It too was reciprocally monophyletic, albeit with lesser Bayesian support (46\%), to a complex of closely related taxa that included $P$. overstreeti, $P$. paralichthydis, and $P$. cynoscionis; $P$. diplectri was the most recent common ancestor to this group.

Babesian inference for SSU rDNA also revealed that both new species comprise discrete evolutionary lineages (Fig. 10). The clade containing observed haplotypes of $P$. notatae sp. n. was monophyletic, having $100 \%$ Bayesian support. In this reconstruction, Philometra nemipteri Luo, 2001 (for which there are no corresponding COI data) was the closest relative and $P$. saltatrix was also closely related. The clade containing observed haplotypes of $P$. aequispiculata sp. n. was also monophyletic, having 100\% support. In this reconstruction, $P$. diplectri was the most closest relative to this new species.

\section{DISCUSSION}

As was mentioned in our introduction, Philometra aequispiculata sp. n. and Philometra notatae sp. n. are so far the only two known nominal species of philometrids parasitising needlefishes (Belonidae) in the region of the Atlantic Ocean. Now it is clear that the female specimens reported by Moravec and Bakenhaster (2012) as Philometra $\mathrm{sp}$. from the ovary of Strongylura marina in the Gulf of Mexico off Florida (Charlotte Harbor) were conspecific with the former species.

Considering the generally high degree of host specificity of gonad-infecting species of Philometra (see e.g., Moravec and Manoharan 2014a,b, Moravec et al. 2014, 2016) and the fact that only males of $P$. aequispiculata but no females were found in Strongylura notata, it may be that this host species serves as only the paradefinitive host for this nematode, whereas its true definitive host is $S$. marina. In contrast to the definitive host, the parasite is unable to reproduce in the paradefinitive host (Odening 1976).

Both newly described philometrid species, $P$. aequispiculata sp. n. and P. notatae sp. n., were collected from the same host species, $S$. notata. This is not exceptional that more than one sympatric species of philometrids with different infection sites occur in the same fish species. For example, three species of Philometra in different sites are known to occur in the red grouper Epinephelus morio (Valenciennes) (Serranidae) in the Gulf of Mexico (Moravec et al. 2010), whereas two species of Philometra and one of Philometroides Yamaguti, 1935 are parasitic in the John's snapper Lutjanus johnii (Bloch) (Lutjanidae) off the northern coast of Australia (Moravec and Barton 2016).

The high level of observed interspecific sequence divergence combined with low intraspecific variation confirmed that the barcode gene COI represents a useful marker for identification of species Philometra. This gene marker was also helpful in reconstructing some of the phylogenetic relationships amongst maternal lineages, although deeper branches within the tree generally lacked Bayesian support. In contrast to the COI findings, most species in the SSU rDNA haplotypes were reconstructed within shallow, weakly supported or non-supported clades. Indeed, sequences for two species, Philometra cyprinirutili 


\section{Bursaphelenchus abruptus_AB067762}

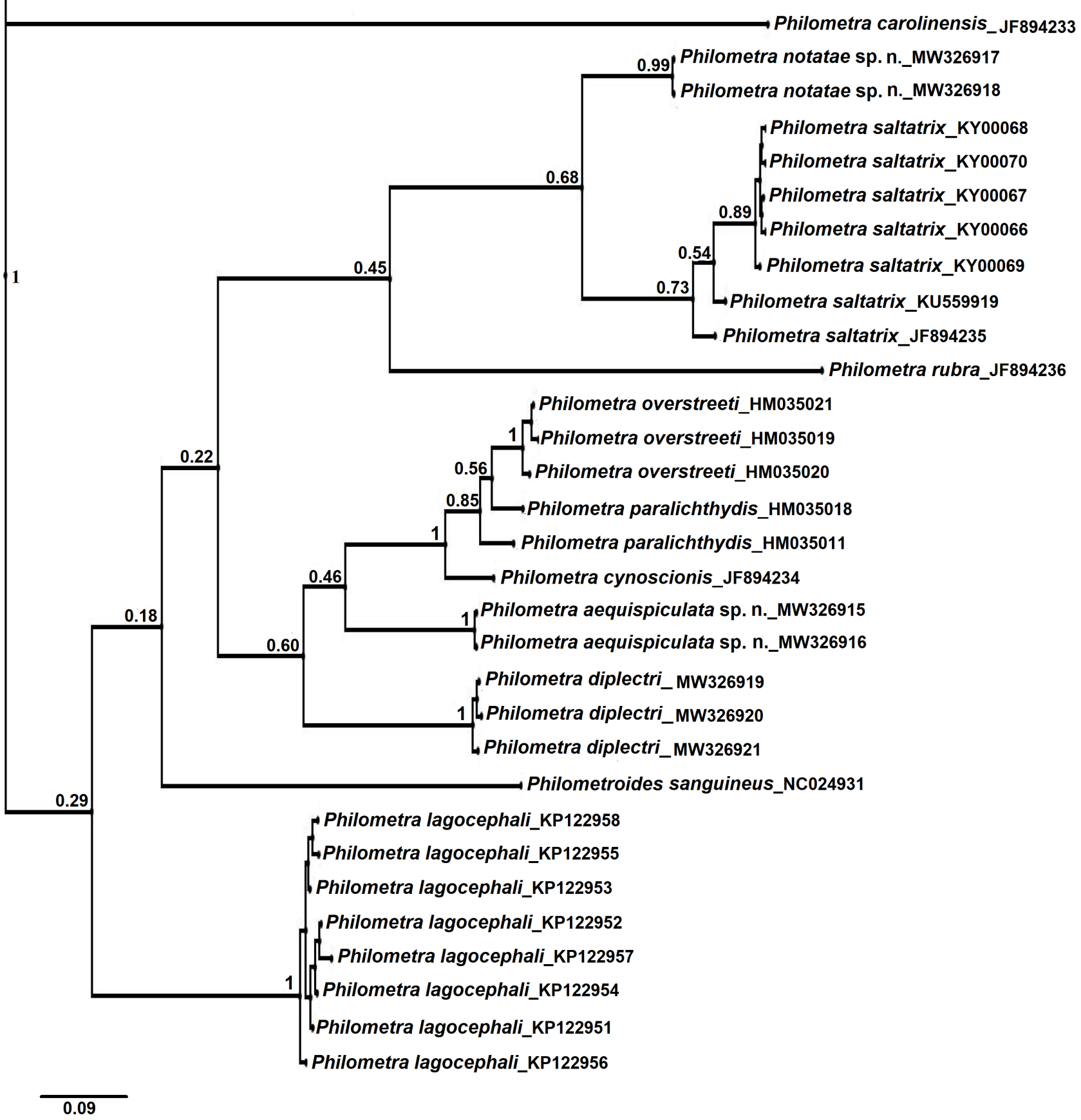

Fig. 9. Phylogenetic tree inferred from Bayesian analyses of cytochrome oxidase subunit 1 (COI) sequences including those from Philometra aequispiculata sp. n. and P. notatae sp. n. from Strongylura (asterisks) and closely related homologous sequences extracted from GenBank. Numbers at the nodes are Bayesian values for Bayesian posterior probability.

(Creplin, 1825) (DQ442675) and Philometra ovata (Zeder, 1803) (DQ442677), became identical when trimmed to the length of $1684 \mathrm{bp}$. For these reasons, this segment of the SSU rDNA does not appear to be practical as a general or standard-alone marker for species identification, nor (in isolation) for the phylogenetic reconstruction of morphologically closely related nematodes.

Moreover, the overal tree contained paraphyletic and polyphyletic patterns within and among genera, suggestive of the need for further molecular assessment as has been previously noted by Moravec (2006). Despite the limited overall resolution within the SSU rDNA tree, the molecular data provided comparatively good support for species-level recognition of $P$. notatae sp. n. and $P$. aequispiculata sp. $\mathrm{n}$., in terms of sequence divergence and (where applicable) Bayesian support for intraspecific haplotypes, relative to the great majority of taxa represented therein.

Whereas the objective of this work was not to develop a stand-alone molecular argument for recognition of $P$. notatae sp. n. and $P$. aequispiculata sp. n., the molecular data 


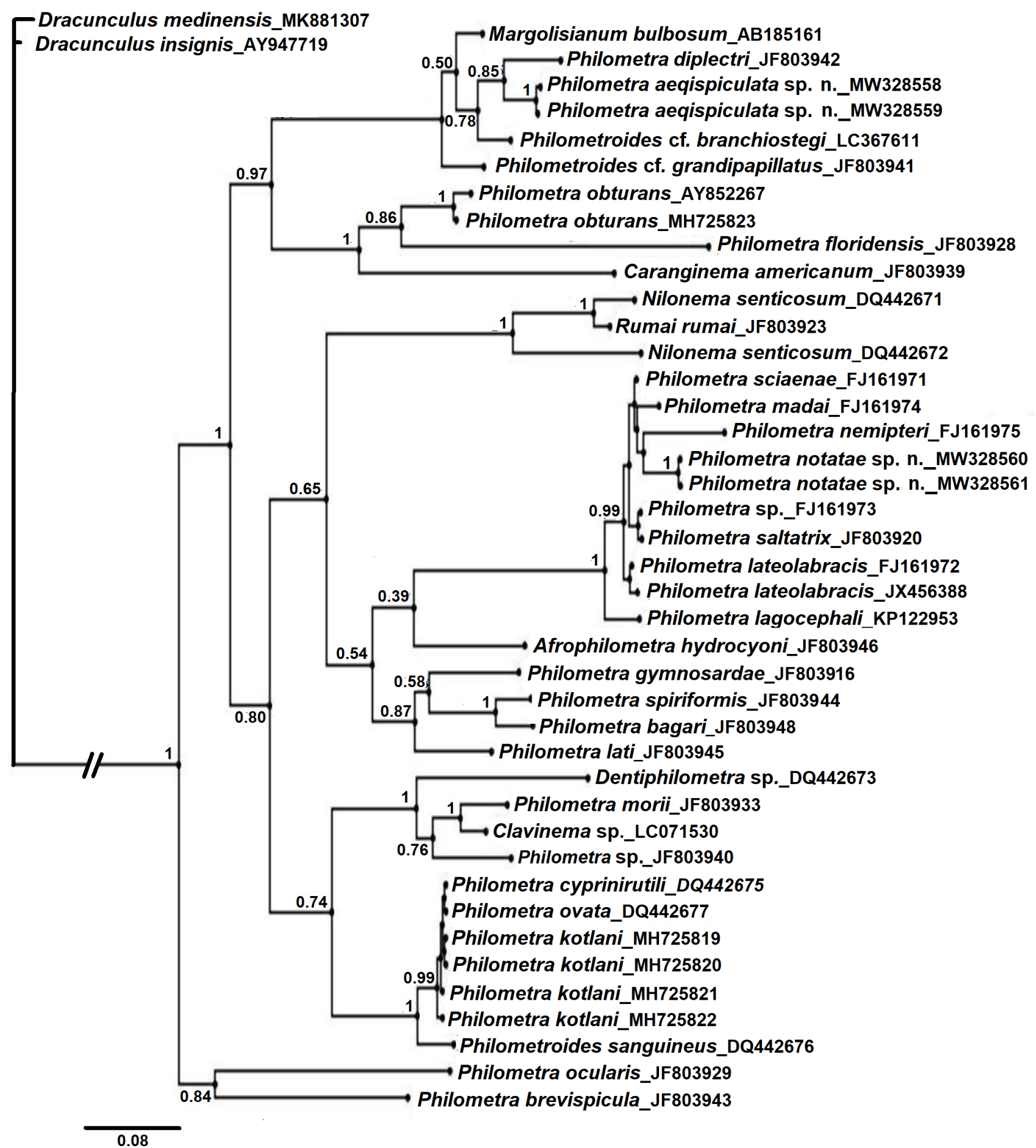

Fig. 10. Phylogenetic tree inferred from Bayesian analyses of small subunit rRNA (SSU rRNA) sequences including those from Philometra aequispiculata sp. n. and P. notatae sp. n. (asterisks) and closely related homologous sequences extracted from GenBank (note that Moravec and de Buron [2006] considered Margolisianum bulbosum Blaylock et Overstreet, 1999 to be a genus inquirendum and a species inquirenda and incertae sedis). Numbers at the nodes are Bayesian values of posterior probability.

are supportive of these respective hypotheses. Under the Evolutionary Species Concept (Wiley 1981), criteria for new species recognition are threefold - the candidate species must possess: 1) a separate and distinct "ancestor-descendant lineage", 2) its own evolutionary tendencies, and 3) an independent evolutionary fate. As discussed above for both gene markers, the first criterion was robustly supported within the current degree of molecular sampling.
Diminishing morphological, biological, and ecological factors (e.g., host specificity), discussed elsewhere in this work, provide supportive evidence for the second and third criteria of this recognition concept.

A related concept, commonly referred to as the Genealogical Species Concept (Baum and Shaw 1995) is further conditioned on the observed state of 'reciprocal monophyly'in nuclear gene genealogies. Thus, the genealogical con- 
Table 2. Number of observed sequence differences for SSU rRNA between select pairs of taxa that occupy the monophyletic clade with Philometra notatae sp. n. below the diagonal; pairwise p-distances are given above the diagonal.

\begin{tabular}{|c|c|c|c|c|c|c|c|}
\hline & $\begin{array}{l}\text { Philometra nota- } \\
\text { tae sp. n. } 1,671 \mathrm{bp}\end{array}$ & $\begin{array}{l}\text { Philometra ne- } \\
\text { mipteri } 1,620 \text { bp }\end{array}$ & $\begin{array}{c}\text { Philometra } \\
\text { madai } 1,635 \mathrm{bp}\end{array}$ & $\begin{array}{l}\text { Philometra sci- } \\
\text { aenae } 1,664 \mathrm{bp}\end{array}$ & $\begin{array}{c}\text { Philometra } \\
\text { saltatrix } 1,648 \text { b }\end{array}$ & $\begin{array}{l}\text { Philometral } \\
\text { plabracis } 1,5 \mathrm{~S}\end{array}$ & $\begin{array}{l}\text { ometra lago- } \\
\text { hali } 1,650 \mathrm{bp}\end{array}$ \\
\hline Philometra notatae sp. n. & ------ & 0.015 & 0.008 & 0.007 & 0.009 & 0.009 & 0.015 \\
\hline Philometra nemipteri & 24 & ------ & 0.012 & 0.010 & 0.013 & 0.011 & 0.019 \\
\hline Philometra madai & 13 & 20 & ------ & 0.002 & 0.004 & 0.005 & 0.010 \\
\hline Philometra sciaenae & 11 & 16 & 4 & ------ & 0.002 & 0.002 & 0.009 \\
\hline Philometra. saltatrix & 14 & 20 & 6 & 4 & ------ & 0.004 & 0.010 \\
\hline Philometra lateolabracis & 15 & 17 & 8 & 4 & 6 & ------ & 0.008 \\
\hline Philometra. lagocephali & 24 & 30 & 16 & 15 & 16 & 13.5 & ------ \\
\hline
\end{tabular}

Table 3. Number of observed sequence differences for SSU rRNA between select pairs of taxa that occupy a monophyletic clade with (1-5) and sister clade to (6-8) Philometra aequispiculata sp. n. below the diagonal; pairwise p-distances are given above the diagonal.

\begin{tabular}{|c|c|c|c|c|c|c|c|c|}
\hline & $\begin{array}{c}\text { Philometra } \\
\text { aequispiculata } \\
\mathrm{sp} . \mathrm{n} .1,487 \mathrm{bp} \\
\end{array}$ & $\begin{array}{l}\text { Philometra di- } \\
\text { plectri } 1,734 \mathrm{bp}\end{array}$ & $\begin{array}{l}\text { Philometroides } \\
\text { cf. branchioste- } \\
\text { gi } 1,700 \mathrm{bp}\end{array}$ & $\begin{array}{c}\text { Margolisianum } \\
\text { bulbosum } \\
1,734 \mathrm{bp}\end{array}$ & $\begin{array}{c}\text { Philomteroides } \\
\text { grandipapilla- } \\
\text { tus } 1,754 \mathrm{bp} \\
\end{array}$ & $\begin{array}{l}\text { Philometra ob- } \\
\text { turans } 1,733 \mathrm{bp}\end{array}$ & $\begin{array}{c}\text { Philometra } \\
\text { floridensis } \\
1,734 \mathrm{bp} \\
\end{array}$ & $\begin{array}{c}\text { Caranginema } \\
\text { americanum } \\
1,691 \mathrm{bp} \\
\end{array}$ \\
\hline $\begin{array}{l}\text { Philometra } \\
\text { aequispiculata } \\
\text { sp. } \mathrm{n} .\end{array}$ & ------- & 0.011 & 0.013 & 0.012 & 0.021 & 0.045 & 0.056 & 0.051 \\
\hline $\begin{array}{l}\text { Philometra } \\
\text { diplectri }\end{array}$ & 16.5 & -------- & 0.009 & 0.008 & 0.018 & 0.059 & 0.073 & 0.054 \\
\hline $\begin{array}{l}\text { Philometroides } \\
\text { cf. branchiostegi }\end{array}$ & 18.5 & 16 & ------- & 0.012 & 0.016 & 0.054 & 0.063 & 0.057 \\
\hline $\begin{array}{l}\text { Margolisianum } \\
\text { bulbosum }\end{array}$ & 17.5 & 13 & 21 & ------- & 0.017 & 0.059 & 0.071 & 0.052 \\
\hline $\begin{array}{l}\text { Philomteroides } \\
\text { grandpapillatus }\end{array}$ & 31 & 32 & 28 & 29 & ------- & 0.061 & 0.069 & 0.055 \\
\hline $\begin{array}{l}\text { Philometra } \\
\text { obturans }\end{array}$ & 62 & 98 & 89 & 98 & 101 & ------- & 0.068 & 0.055 \\
\hline $\begin{array}{l}\text { Philometra } \\
\text { floridensis }\end{array}$ & 79.5 & 123 & 105 & 120 & 117 & 112.5 & -------- & 0.067 \\
\hline $\begin{array}{l}\text { Caranginema } \\
\text { americanum }\end{array}$ & 71 & 91 & 94 & 87 & 93 & 90 & 113 & ------- \\
\hline
\end{tabular}

cept sets the highest bar among all molecular-based approaches. As is evidenced by the SSU rDNA gene phylogeny, this bar was met by specimens of $P$. aequispiculata $\mathrm{sp} . \mathrm{n}$. in relation to Philometra diplectri, which was unsurprising in the absence of representative sequences for Philometra overstreeti, Philometra paralichthydis, and Philometra cynoscionis. It remains to be seen if this criterion obtains upon a more comprehensive molecular analysis with expanded taxonomic sampling.

Acknowledgements. We thank our many FWRI colleagues, including Adam Richardson, Clark Gray, Maki Tabuchi, Kristina Deak, Yasunari Kiryu and Eli Bastian, who assisted in fish necropsies. The names of FWRI Fisheries Independent Monitoring field and laboratory biologists who made this study possible would well exceed reasonably available space here, but we are grateful to each of them. Thanks are also due to the Laboratory of Electron Microscopy, Institute of Parasitology, Biology Centre CAS, institution supported by the MEYS CR (LM2015062
Czech-BioImaging) and ERDF (No. CZ.02.1.01/0.0/0.0/16_013 /0001775), for their support with obtaining SEM data presented in this paper, and to Blanka Škoríková of the same Institute for help with the illustrations. This study was partly supported by the institutional support of the Institute of Parasitology, BC AS CR (60077344). Funding for fish and parasite collection and DNA sequencing was derived from State of Florida saltwater recreational fishing license revenues, or the US Department of the Interior (DOI), U.S. Fish and Wildlife Service (USFWS) Wildlife and Sport Fish Restoration program (WSFR) (F16AF00898, F17AF00793, F16AF00544, F17AF00932, and F18AF00524). Statements, conclusions and recommendations are those of the authors and do not necessarily reflect the views or policies of the DOI or the USFWS. Any opinions, views, statements, findings, conclusions, and recommendations expressed in this material are those of the authors; they do not necessarily reflect, and should not be interpreted as presenting, the opinions, views, or policies of the USFWS, WSFR, or the DOI. Nothing contained herein constitutes an endorsement in any respect by any part of the U.S. Government or the State of Florida. 


\section{REFERENCES}

Altschul S.F., Gish W., Miller W., Myers E.W., Lipman D.J. 1990: Basic local alignment search tool. J. Mol. Biol. 215: 403-410.

Baum D.A., Shaw K.L. 1995: Genealogical perspectives on the species problem. In: P.C. Hoch, A.G. Stephenson (Eds.), Experimental and Molecular Approaches to Plant Biosystematics. Missouri Botanical Garden, St. Louis, pp. 289-303.

de Buron I., France S.G., Connors V.A., Roumillat W.A., Tsoi L.C. 2011: Philometrids of the southern flounder Paralichthys lethostigma: a multidimensional approach to determine their diversity. J. Parasitol. 97: 466-475.

Černotíková E., Horák A., Moravec F. 2011: Phylogenetic relationships of some spirurine nematodes (Nematoda: Chromadorea: Rhabditida: Spirurina) parasitic in fishes inferred from SSU rRNA gene sequences. Folia Parasitol. 58: 135-148.

Floyd R., Abebe E., Papert A., Blaxter M. 2002: Molecular barcodes for soil nematode identification. Mol. Ecol. 11: 839850.

Froese R., Pauly D. (Eds.) 2020: FishBase. World Wide Web electronic publication, http://www.fishbase.org, version 06/2020.

Hasegawa H., Williams E.H., Bunkley-Williams L. 1991: Nematode parasites from marine fishes of Okinawa, Japan. J. Helminthol. Soc. Wash. 58: 186-197.

Holterman M., van der Wurff A., van den Elsen S., van Megen H., Bongers T., Holovachov O., Bakker J., HelDER J. 2006: Phylum-wide analysis of SSU rDNA reveals deep phylogenetic relationships among nematodes and accelerated evolution toward crown clades. Mol. Biol. Evol. 23: 1798-1800.

JACOB E., PALM H.W. 2006: Parasites of commercially important fish species from the southern Java coast, Indonesia, including the distribution pattern of trypanorhynch cestodes. Verhandl. Gessell. Ichthyol. 5: 163-191.

Kiryu Y., Landsberg J.H., Bakenhaster M.D., Tyler-Jedlund A.J., Wilso P.W. 2018: Putative histiocytic sarcoma in redfin needlefish Strongylura notata (Beloniformes: Belonidae) in Florida USA. Dis. Aquat. Org. 132: 57-78.

Linton E. 1907: Notes on parasites of Bermuda fishes. Proc. U. S. Nat. Mus. 33: 85-126.

Mohamed A.H., Hassan M.A., Mahmoud M.A. 2010: Infestation of some marine fish species with red worm Philometra. Arab Gulf J. Sci. Res. 28: 137-146.

Moravec F. 1978: Redescription of the nematode Philometra $o b$ turans (Prenant, 1886) with a key to the philometrid nematodes parasitic in European freshwater fishes. Folia Parasitol. 25: 115124.

Moravec F. 2006: Dracunculoid and Anguillicoloid Nematodes Parasitic in Vertebrates. Academia, Prague, 634 pp.

Moravec F. 2008: Systematic status of Philometra jordano (López-Neyra, 1951) and some other congeneric species previously identified as Philometra lateolabracis (Yamaguti, 1935) (Nematoda: Philometridae). Folia Parasitol. 55: 159-160.

Moravec F., Ali A.H. 2005: Two new species of Philometra (Nematoda: Philometridae) from needlefishes (Belonidae) in Iraq, with a key to Philometra spp. parasitic in the host's subcutaneous tissue, fins and musculature. Folia Parasitol. 52: 267-273.

Moravec F., Bakenhaster M. 2010: A new species of Philometra (Nematoda: Philometridae) from the sand perch Diplectrum formosum (Serranidae) off Florida, northern Gulf of Mexico. J. Parasitol. 96: 987-992.

Moravec F., Bakenhaster M. 2012: New observations on philometrid nematodes (Philometridae) in marine fishes from the northern Gulf of Mexico and the Indian River Lagoon of Florida (USA), with first description of the male of Caranginema americanum. J. Parasitol. 98: 398-403.
Moravec F., Bakenhaster M., Fajer-Ávila E.J. 2010: New philometrids (Nematoda, Philometridae) from head tissues of two serranid fishes (Epinephelus morio and Mycteroperca microlepis) off Florida, northern Gulf of Mexico. Acta Parasitol. 55: 359-368.

Moravec F., Bakenhaster M., Fajer-Ávila E.J. 2014: Three new gonad-infecting species of Philometra (Nematoda: Philometridae) parasitic in Lutjanus spp. (Lutjanidae) in the northern Gulf of Mexico off Florida, USA. Folia Parasitol. 61: 355-369.

Moravec F., Barton D.P. 2016: New tissue-dwelling species of Philometra Costa, 1845 and Philometroides Yamaguti, 1935 (Nematoda: Philometridae) from marine perciform fishes off the northern coast of Australia. Syst. Parasitol. 93: 623-637.

Moravec F., De Buron I. 2006: Two species of philometrid nematodes (Nematoda: Philometridae) from the southern flounder Paralichthys lethostigma off South Carolina, USA. Folia Parasitol. 53: 139-146.

Moravec F., De Buron I., Roumillat W.A. 2006: Two new species of Philometra (Nematoda: Philometridae) parasitic in the perciform fish Cynoscion nebulosus (Sciaenidae) in the estuaries of South Carolina, USA. Folia Parasitol. 53: 63-70.

Moravec F., Chaabane A., Neifar L., Gey D., Justine J.-L. 2016: Descriptions of Philometra aenei n. sp. and P. tunisiensis n. sp. (Nematoda: Philometridae) from Epinephelus spp. off Tunisia confirm a high degree of host specificity of gonad-infecting species of Philometra Costa, 1845 in groupers (Serranidae). Syst. Parasitol. 93: 115-128.

Moravec F., Cutmore S.C., Yong R.Q.-Y. 2018: Redescription of Philometra pellucida (Jägerskiöld, 1893) (Nematoda: Philometridae) parasitic in the abdominal cavity of the blackspotted puffer Arothron nigropunctatus (Bloch \& Schneider) (Teleostei: Tetraodontidae) off Australia and Japan. Syst. Parasitol. 95: 665-671.

Moravec F., Justine J.-L. 2009: New data on dracunculoid nematodes from fishes off New Caledonia, including four new species of Philometra (Philometridae) and Ichthyofilaria (Guyanemidae). Folia Parasitol. 56: 129-142.

Moravec F., Manoharan J. 2014a: Gonad-infecting species of Philometra (Nematoda: Philometridae) from groupers Epinephelus spp. (Osteichthyes: Serranidae) in the Bay of Bengal, India. Acta Parasitol. 59: 596-605.

Moravec F. Manoharan J. 2014b: Two new gonad-infecting species of Philometra (Nematoda: Philometridae) parasitic in Lutjanus spp. (Osteichthyes: Lutjanidae) in the Bay of Bengal, India. Parasitol. Res. 113: 3299-3307.

Moravec F., Rohde K. 1992: Three species of nematodes of the superfamily Dracunculoidea from Australian fishes. Acta Soc. Zool. Bohemoslov. 56: 187-195.

Moravec F., Vidal-Martínez V.M., Aguirre-Macedo M.L., GonzÁLEZ-Solís D. 2001: First description of the male and redescription of the female of Philometra salgadoi Vidal-Martínez et al., 1995 (Nematoda: Philometridae) from the ocular cavity of the marine fish Epinephelus morio in Mexico. Parasitol. Res. 87: 526-529.

Moravec F., Walter T., Yuniar A.T. 2012: Five new species of philometrid nematodes (Philometridae) from marine fishes off Java, Indonesia. Folia Parasitol. 59: 115-130.

NAIDU T.S.V., ThaKare V.K. 1979: Studies on nematode parasites of Belone cancila and Suncus murinus from Naghpur (M. S.), India. Riv. Parassitol. 40: 281-289.

Nikolaeva V.M., Parukhin A.M. 1968: [Study of fish helminths in the Gulf of Mexico. In: Investigations of the Central-American Seas (Based on Materials of the Soviet-Cuban Marine Expedition), Part II.] Naukova Dumka, Kiev, pp. 126-149. (In Russian with Spanish and English summaries.) 
Obiekezie A.I. 1986: Philometra (Ranjhinema) beninensis sp. nov. (Nematoda: Philometridae) from the giant African threadfin, Polydactylus quadrifiliis Cuvier, 1829 (Teleostei: Polynemidae). Rev. Zool. Afr. 100: 357-361.

Obiekezie A.I., Anders K. 1991: Scanning electron microscope studies on Philometra (Ranjhinema) beninensis Obiekezie, 1986 (Nematoda: Philometridae). Folia Parasitol. 38: 371-374.

ODENING K. 1976: Conception and terminology of hosts in parasitology. Adv. Parasitol. 14: 1-93.

Palesse S., Meadors W.A., de Buron I., Roumillat W.A., STRAND A.E. 2011: Use of molecular tools in identification of philometrid larvae in fishes: technical limitations parallel our poor assessment of their biodiversity. Parasitol. Res. 109: 17251730 .

Petersen F., Palm H., Möller H., Cuzi M.A. 1993: Flesh parasites of fish from central Philippine waters. Dis. Aquat. Org. 15: 81-86.

Rasheed S. 1965: Additional notes on the family Philometridae Baylis and Daubney, 1926. J. Helminthol. 39: 349-362.
Ronquist F., Huelsenbeck J.P. 2003: MrBayes 3: Bayesian phylogenetic inference under mixed models. Bioinformatics 19: $1572-1574$

Tamura K., Stecher G., Peterson D., Filipski A., Kumar S. 2013: MEGA6: version 6.0. Molecular evolutionary genetics analysis. Mol. Biol. Evol. 30: 2725-2729.

Vidal-Martínez V.M., Aguirre-Macedo M.L., Moravec F. 1995: Philometra (Ranjhinema) salgadoi n. sp. (Nematoda: Philometridae) from the ocular cavity of the red grouper Epinephelus morio (Pisces: Serranidae) from the Yucatan Peninsula, Mexico. J. Parasitol. 81: 763-766.

WANG S.-X., Li L., Zhang L.-P. 2015: Redescription and genetic characterization of Philometra lagocephali Moravec et Justine, 2008 (Nematoda: Philometridae) from Lagocephalus lunaris (Bloch and Schneider) (Tetraodontiformes: Tetraodontidae) in the South China Sea. Acta Parasitol. 60: 395-406.

Wiley E.O. 1981: Remarks on Willis' species concept. Syst. Zool. 30: $86-87$.

Cite this article as: Moravec F, Bakenhaster M.D., Seyoum S., Tringali M.D. 2021: Morphological and genetic description of two new species of philometrid nematodes (Philometridae) parasitic in needlefishes (Belonidae) from estuaries of Florida, USA. Folia Parasitol. 68: 008. 